دـ د. عبدالله بن عبدالعزيز الوقيت

\title{
ظاهرة الاتفاق
}

\section{في أحكام المعتلّ والمضعَف في الصرف العربي \\ دراسة وصفية}

د. ـ عبدالله بن عبدالعزيز الوقيت (")

المقدمة :

يلفت المطلّع على كتب النّحويين عند حديثهم عن مسائل التصريف نرديد

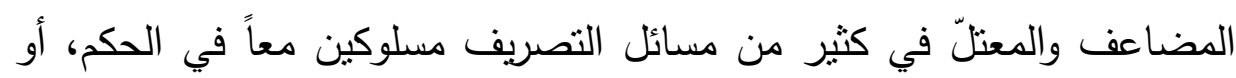
مستثنيين منه، وقد عزمت على تتبع ذلك عند النحويين، وجمعه ومناقشته بغية جعله بين أيدي الباحثين.

ومعلوم أن الأصل في الأحكام التي يطلقها علماء النحو أن تكون شاملة

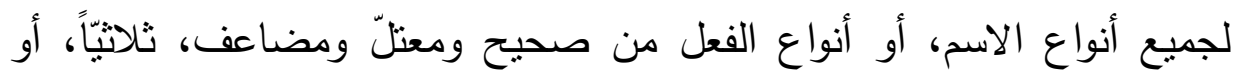

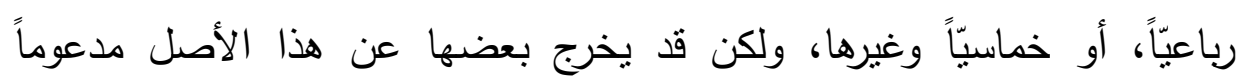

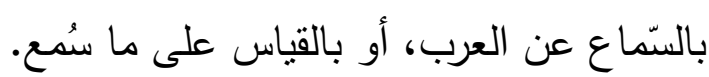

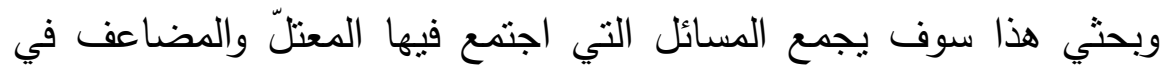

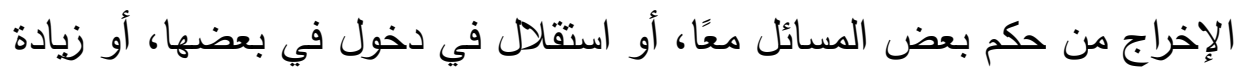

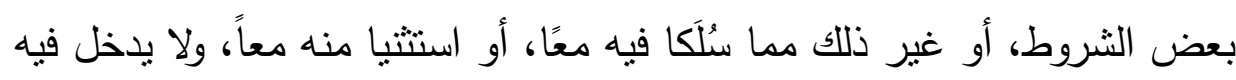

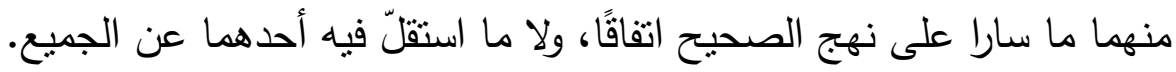
ويهذف هذا البحث إلى ما يأتي: 1-جمع المسائل المتفقة في الحكم بين المعتل والمضاعف في بحتث بـث واحد.

|" الأستاذ الشارك بقسم اللغة العربية وآدابها -كلية اللغة العربية والدراسات الاجتماعية جامعة القصيم • 
ا-إيراز ظاهرة تعاقب المعتل والمضاعف في الصرف العربي، ووصفها. r-إتاحة الفرصة أمام الباحثين المحثثن لدراسة هذه الظاهرة، وتلمس أسبابها الصوتية واللغوية والسماعيّة.

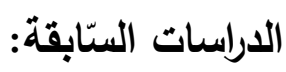

لم أقف - حسب اطلاعي - على دراسة متخصّصة في هذا الموضوع، والذي

وققت عليه دراسات منتوعة تتاولت الموضوع من جوانب مختلفة، ومنها:

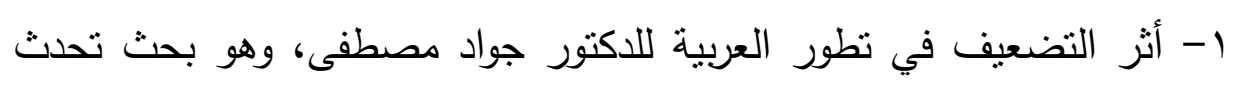

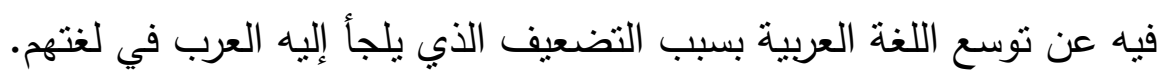

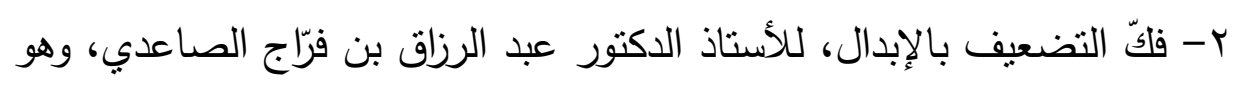

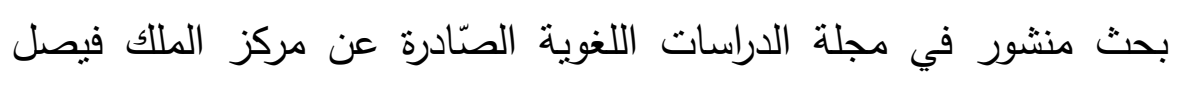

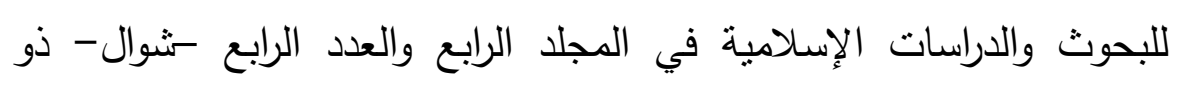

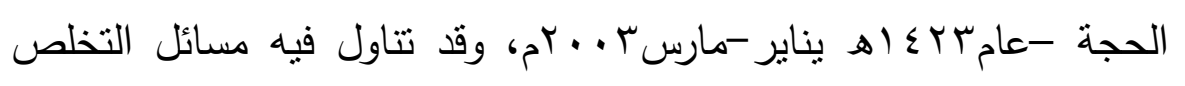

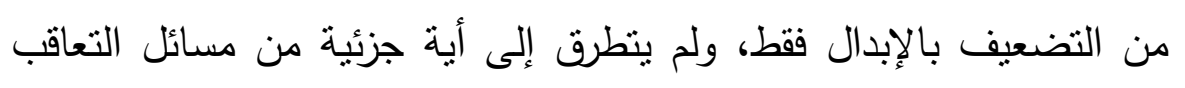
بين التضعيف والمعتلّ.

r- التخلّص من المتماثلات، وهذا بحث نشره الأستاذ الدكتور أبو أوس إبراهيم

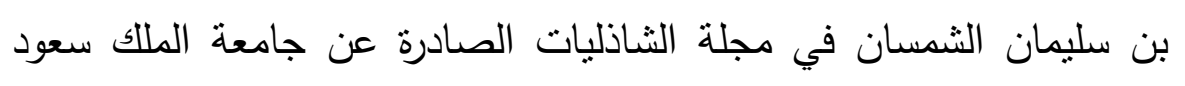

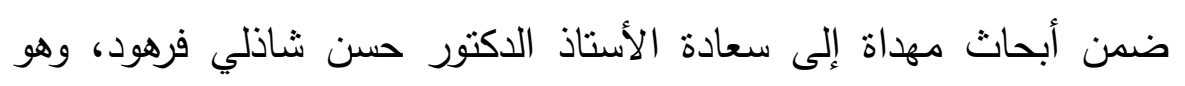

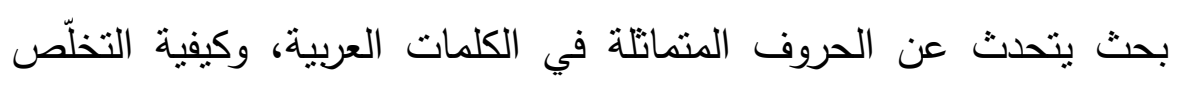

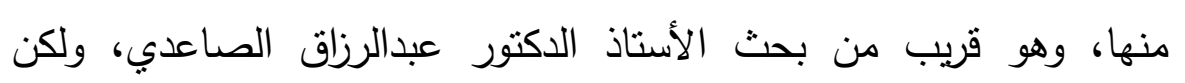
الأخير خص هذا التخلص بالإبدال، بينما أطلقه الأول. ع- من طرق التعامل مع المضعف في العربية واللغات السامية دراسة تحليلية

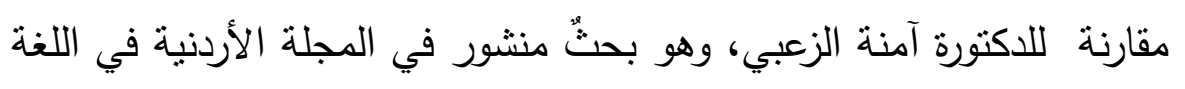

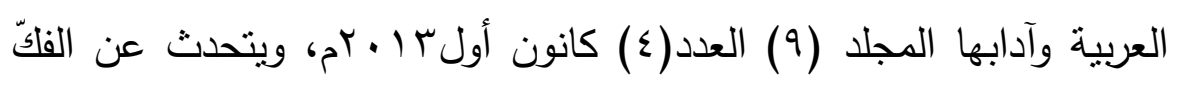




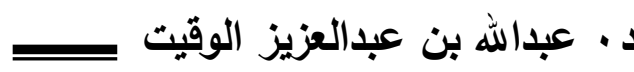

والإدغام في المضعف، ومقارنته باللغات السامية، وبيان الآثار الصوتية بين

$$
\text { العربية واللغات الساميّة، ولم يدخل فيما أنا بصدده. }
$$

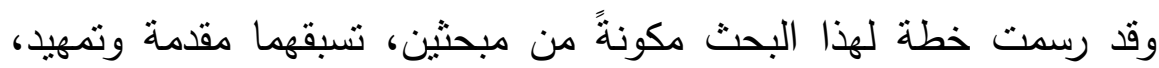

$$
\text { وتتلوهما خاتمة على النحو الآتي: }
$$

"المقدّمة.

*التمهيد، وفيه الإثشارة إلى تعريف المضاعف، وكذلك المعتلّ.

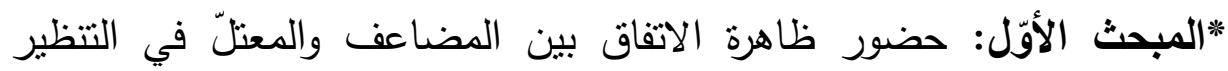

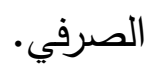

$$
\text { ثأثانياً: الماًا: سيبوده. ابن جنّي. }
$$

"المبحثُ الثاني: عرض أوجه الاتفاق بين المضعّف والمعتلّ في التنظير

$$
\text { الصرفي. }
$$

$$
\text { المطلب الأول: عرض أوجه الاتفاق في أوزان الجموع. }
$$

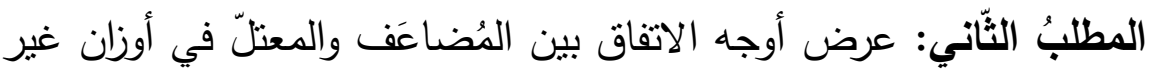

$$
\begin{aligned}
& \text { المطلب الثالث: أوجه حمل أحدهما على الآخر والعكس. }
\end{aligned}
$$

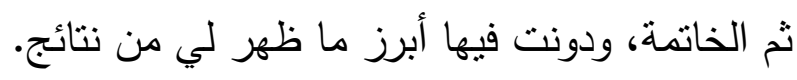

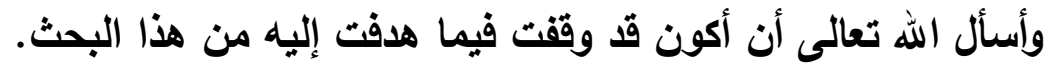




\section{التمهيذ}

أوّلاً: تعريف المضعَف وأنواعه:

المضعَّف: عرفه الخليل بقوله:"التضعيفُ أن يزاد على الثيء متلهه، فيجعل

اثثين أو أكثر"(').

وقال سييويه:"التضعيف أن يكون آخر الفعل حرفان من موضعِ واحد"(Y)"،

وهو نوعان: مضعَف الرباعي، ومضعف الثناثي.

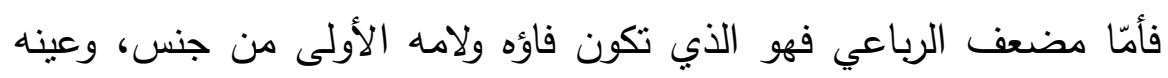

ولامه الثانية من جنس آخر، نحو : زلزل، ودمدم، وعسعس، ويسمّى مطابقا أيضاً.

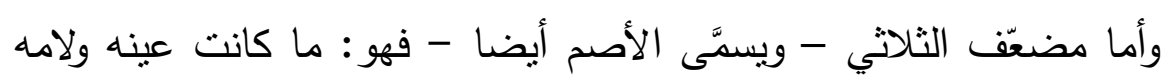

من جنس واحد.

وقولنا: عينه ولامه يخرج به ما كان فيه حرفان من جنس واحد، ولكن ليس

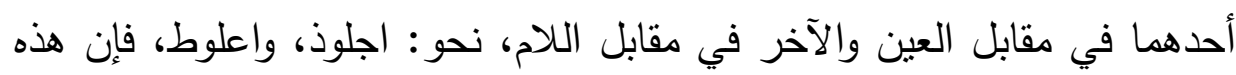

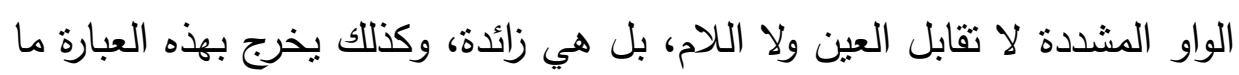

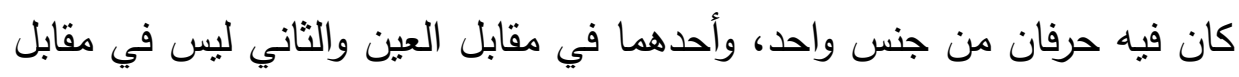

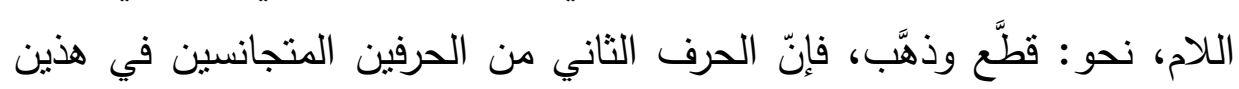

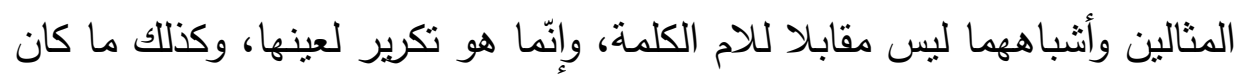

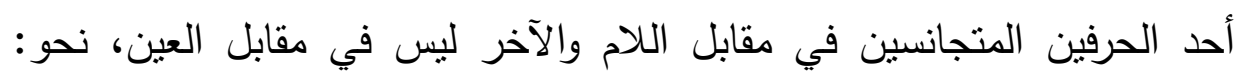

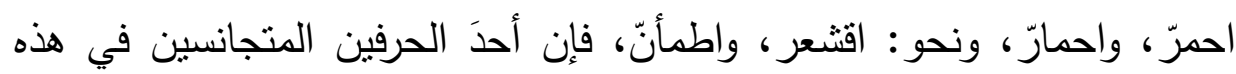
الهتل ونحوها ليس في مقابلة العين، بل هو تكرير للاجِ الكلمة (؟).

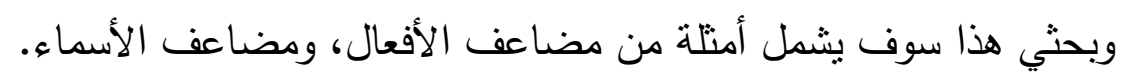

$$
\begin{aligned}
& \text { (1) ندريج الأداني إلى قراءة شرح السعد على تصريف الزنجانيو9. }
\end{aligned}
$$

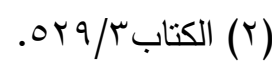

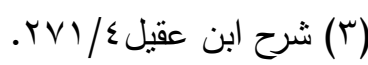

$$
\begin{aligned}
& \text {-VOY- }
\end{aligned}
$$




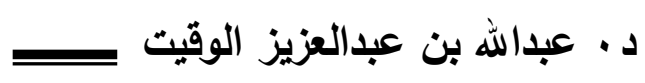

ثانياً: تعريف المعتلّ، وأنواعه:

المعتلّ هو ما كان أحدُ حروفه الأصليّة حرف علّة (').

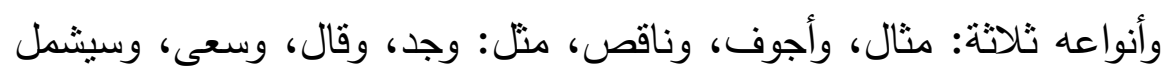

البحث أمثلة من معتل الأفعال، ومن معتل الأسماء.

(1) ينظر : تدريج الأداني إلى قراءة شرح السعد على تصريف الزنجاني^11.

$-\mathrm{VOH}-$ 


\section{المبحث الأوّل}

\section{حضور ظاهرة الاتفاق بين المضاعف والمعتّ}

\section{في التظظير الصرفي}

معلومٌ أنّ الغالب في المعتلّ والمضتَاعف أن يجيء فيهما من الأحكام

والأوزان ما يجيء في الصّحيح، ونصّ على هذا النّحْويّون (').

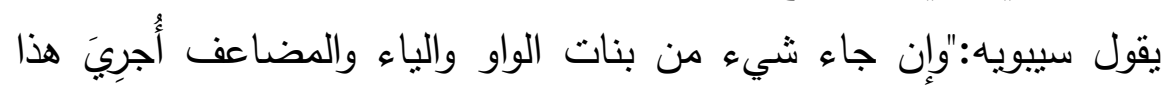

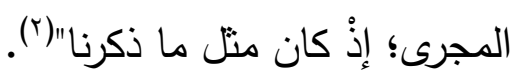

ويقول ابن عصفور معتّلا لبعض المسائل:"المعتلَّ والمضعَّف الغالبُ فيهما

أن يجيء فيهما من الأوزان ما يجيء في الصّحيح"(").

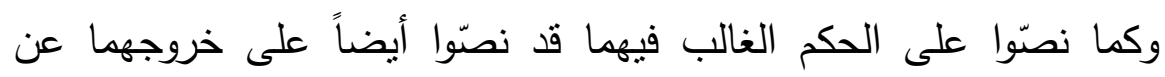

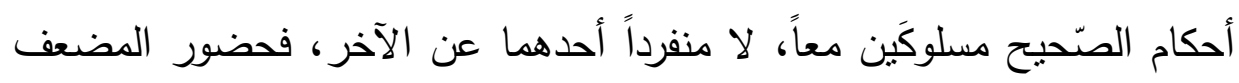

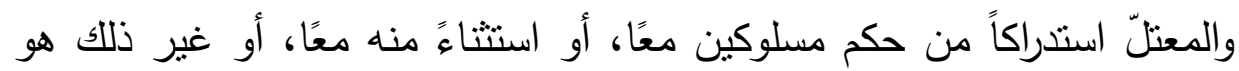

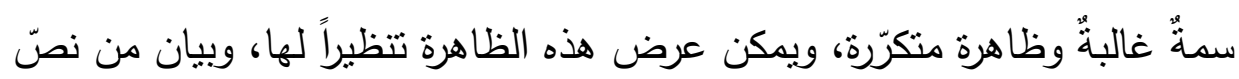
عليها من النحويين، وأمكنة ذلك في كتب النحو العربي، وذللك على النّحو الآتي:

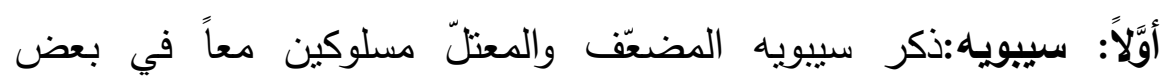
الأحكام، وذلك في عدد من أبواب كتابه، ومنها -على سبيل التمثيل-ما يأتي: 1-باب ما شذّ من المضعف، إذ يقول:"اعلم أنّ لغةً للعرب مطرّدةً يجري فيها

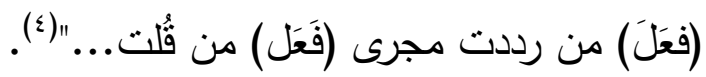

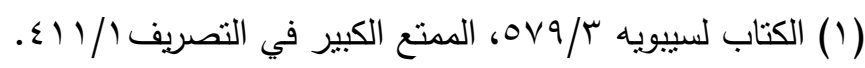

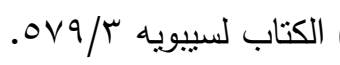

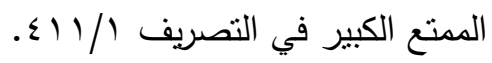

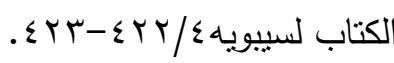




\section{د. . عبدالله بن عبدالعزيز الوقيت}

r- باب تكسير الواحد للجمع، إذ يقول:"وإن جاء شيءٌ من بنات الياء والواو

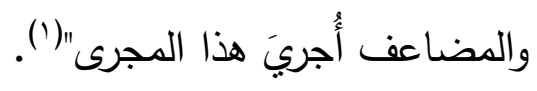

r-باب جمع التكسير أيضاً حضرا معاً فيقول سيبويه:"وأمَّا ما كان من بنات الياء

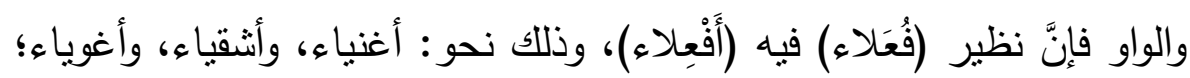

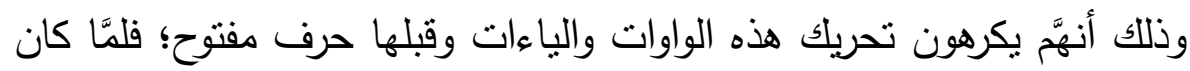

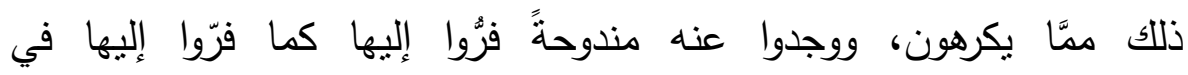
المضَّاعَف (r)".

ـ-باب التضعيف، يقول سييويه:"ألا نرى أنهم أجروا فعلاً اسماً من التضعيف

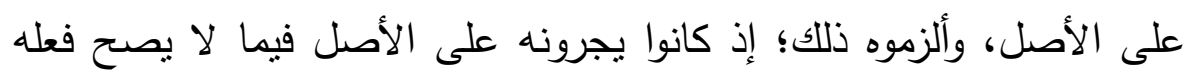

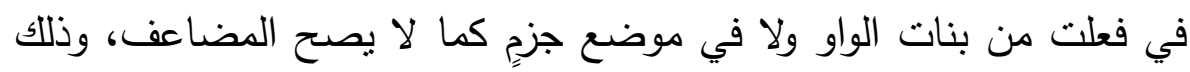

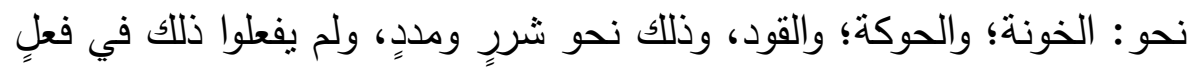

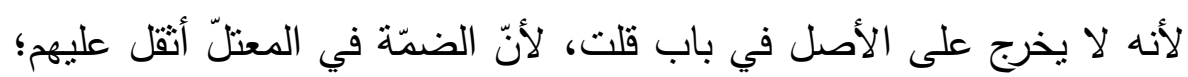
ألا ترى أنك لا تكاد تجد فعلاً في التضعيف ولا فعلاً" (ن).

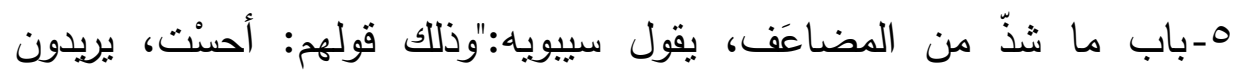

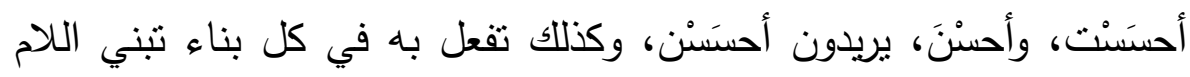
من الفعل فبه على السكون، ولا تصل إليها الحركة، شبهوها بـ (أقتى)، لأنهم

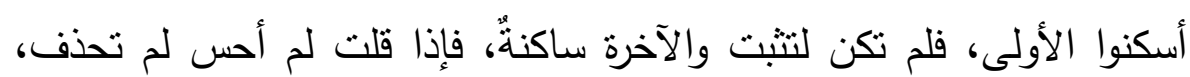

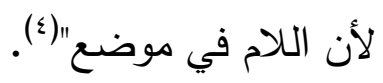

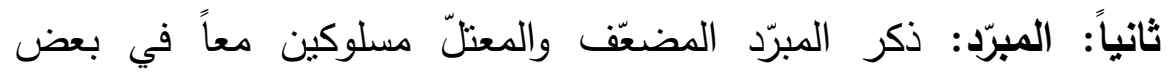
الأحكام، وذللك في عدد من أبواب كتابه، ومنها -على سبيل التمثيل-ما يأتي:

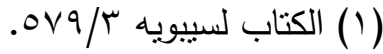

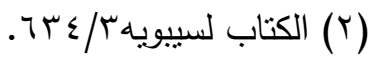

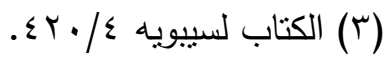

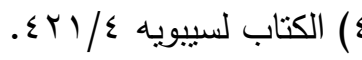




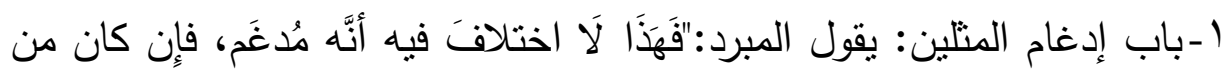

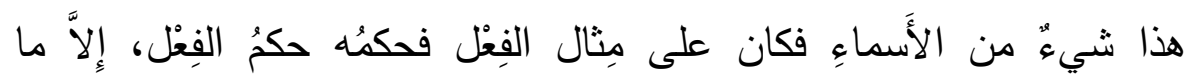

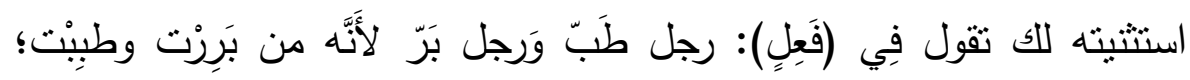

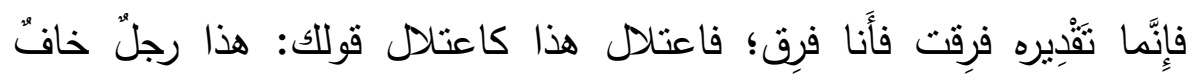

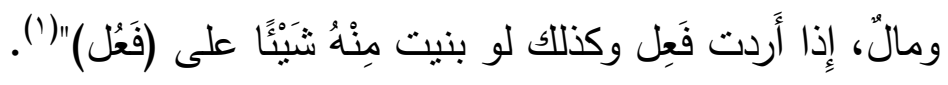

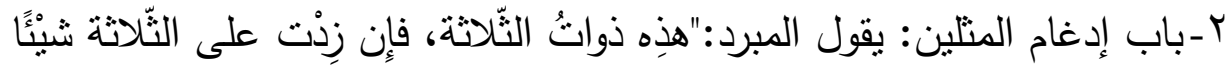

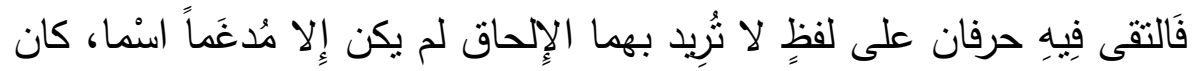

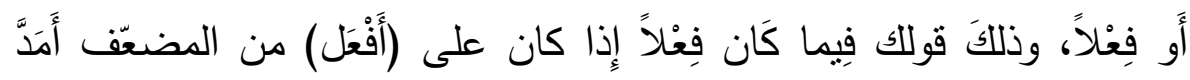

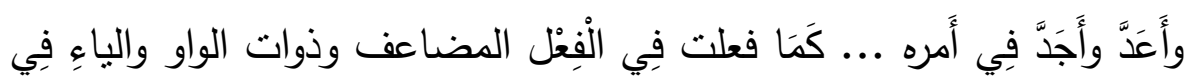

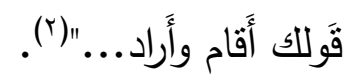

r-باب ما شبه من المضَاعف بالمعتلّ: قال المبرد:"وذللك قوللك فِي أَحْسَسْت

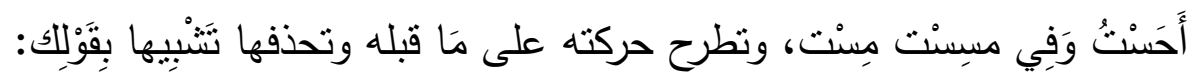

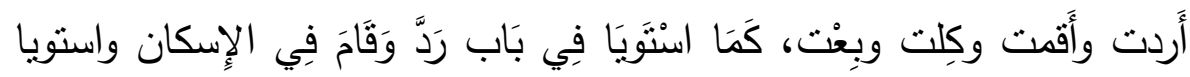

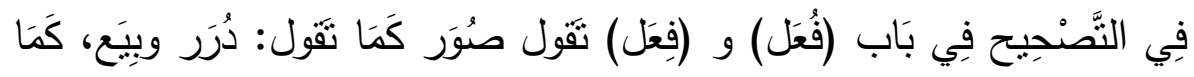

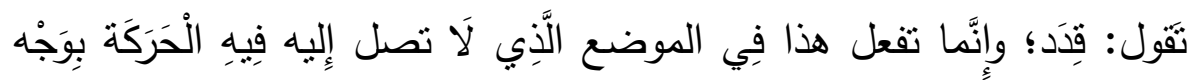

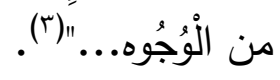

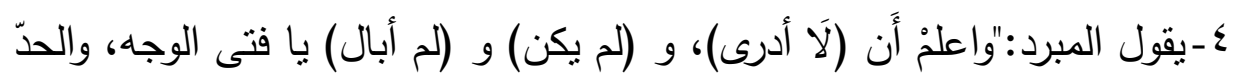

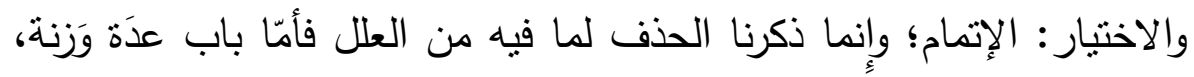

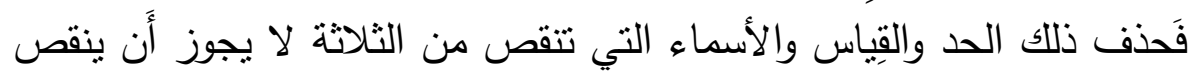

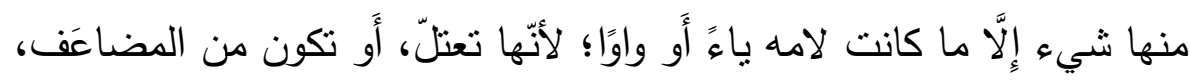
فتحذف للاستثقال"(i).

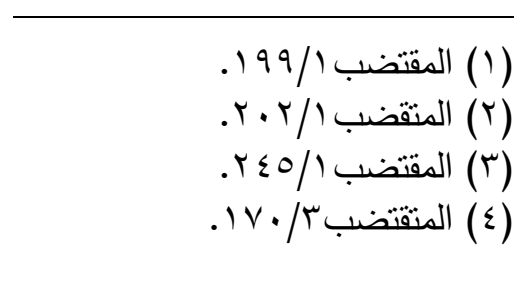




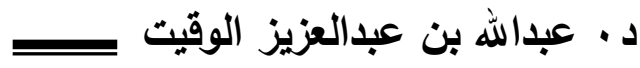

هـ هذا باب ما كان من فعل: يقول المبرد:"فَإن كانَ من ذوات الواو والياء، أَو مِمَّا

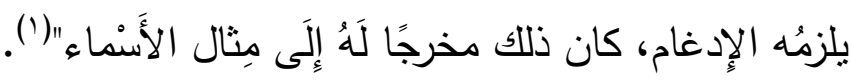

ثالثاً: ابن جني: ذكر ابن جني المضعَّ والمعتلّ مسلوكين معاً في بعض الأحكام، وذللك في عدد من أبواب بعض كتبه، ومنها -على سبيل التمثيل-ما

ا -باب في التقديرات المختلفة لمعنيين مختلفين: يقول ابنُ جني:"ومن ذلك قولهم: مُخْتار ومُعْتاد، ونحو ذلك، فهذا يحمل تقديرين مختلفين لمعنبين مختلفين؛ وذلك أنه إن كان اسم الفاعل فأصله مختير ومعتوِد.... وإن كان مفعولاً فأصله وديله مختيرر ومعتوَد... فهذان تقديران مختلفان لمعنيين؛ وإنما كان يكون هذا منكرًا لو كان تقدير فتح العين وكسرها لمعنى واحد، فأمّا وهما لمعنيين فسائغ حسن، وكذلك ما كان من المضعّف في هذا الشرحمن الكلام..."(r). r-باب ما جاء من الأسماء ليس في أوله زيادة، يقول ابن جني:"قد يحركون عين نحو (سور)، و(سوور) في الثعر، كما يفكّون المضاعف نحو: ضننوا،

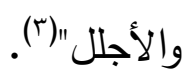
r-باب ما الياء والواو فيه ثانية: يقول ابن جني:"وقد أجروا المدغم مجرى المعتلّ في هذا الباب، لموافقته إياه في سكون العين"(أ).

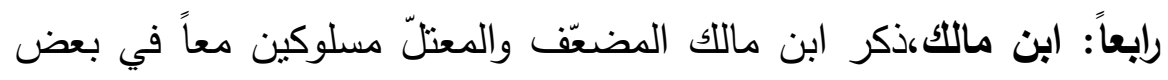
الأحكام، وذلك في عدد من أبواب بعض كتبه، ومنها -على سبيل التمثيل-ما 
1-باب النائب عن الفاعل: يقول ابن ماللك:"ويجوز في فاء الثلاثي المضعّف من

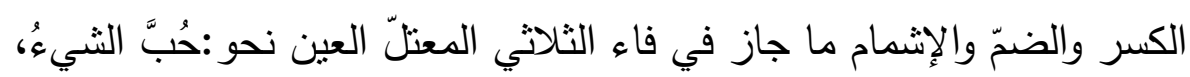

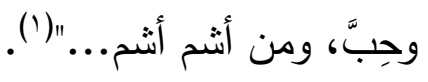

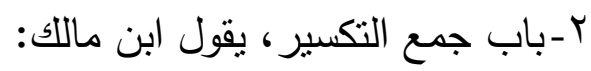

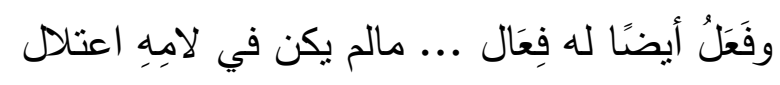

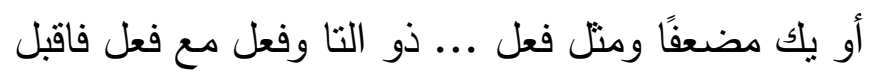

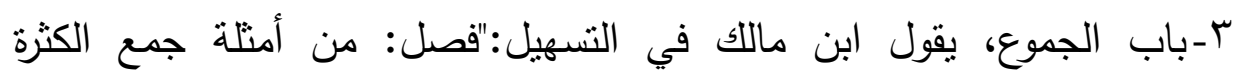

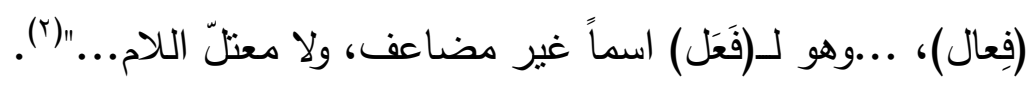

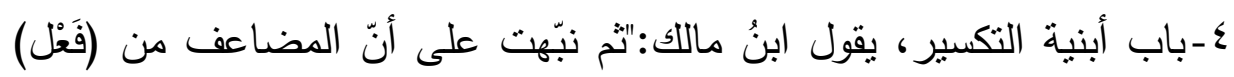

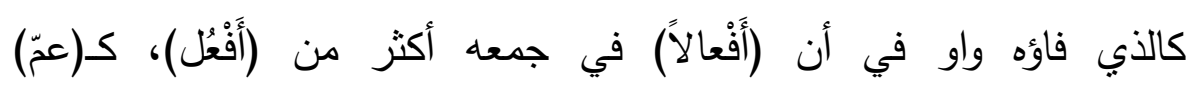

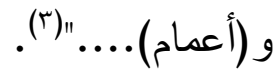

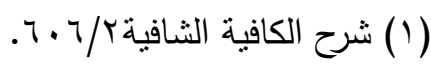

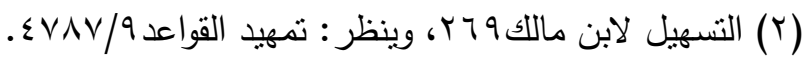

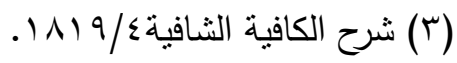


د د أ. عبدالله بن عبدالعزيز الوقيت

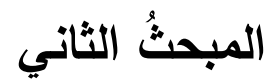

عرض أوجه الاتفاق بين المضعق والمعتّل

في التظظير الصّرفي

المطلب الأوّل: عرض أوجه الاتفاق في أوزلان الجمْع:

$$
\text { أولاًا: وزن (فُعَلاء): }
$$

وجدَ النّحويون العربَ يَجْمَعُون ما كان صفةًَ بزنة (فعيل) التي بمعنى فاعل جمعَ تكسيرٍ على (فُعَلاء)، متل: صريح: صُرَحاء، كريم: كُرَمَاء.

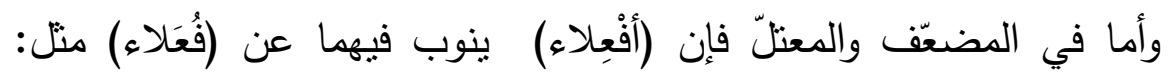
شديد: أَثنِدّاء، وغَنَيّ: أَغْنِياء (1).

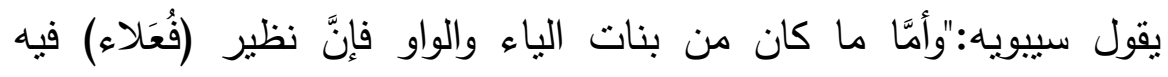

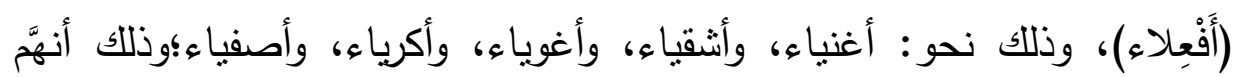

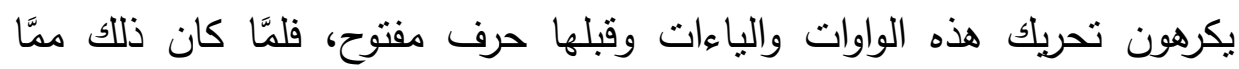

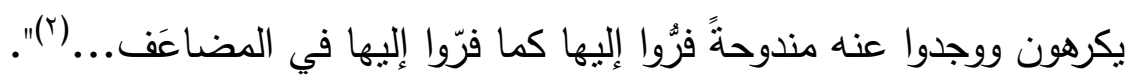

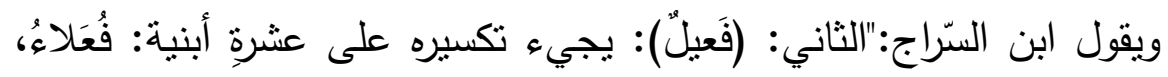

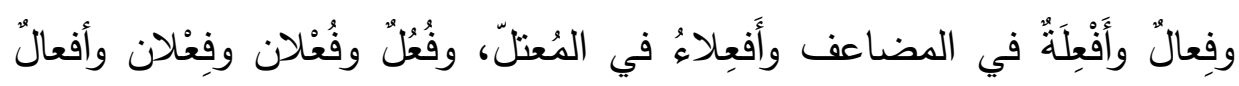

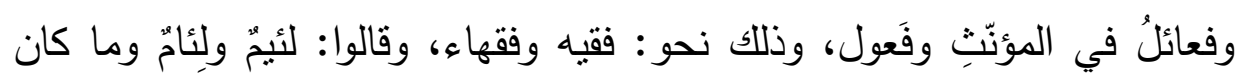

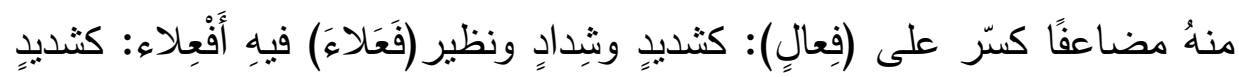

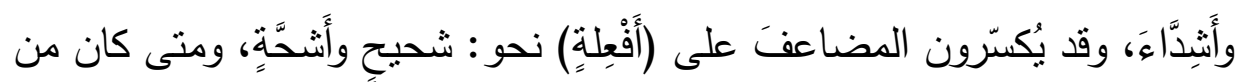

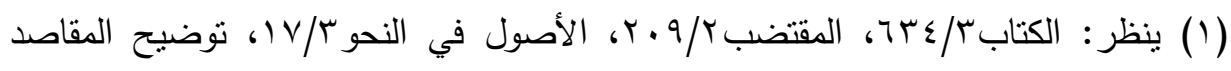

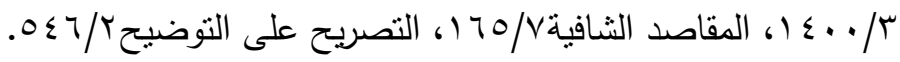




\section{ظاهرة الاتفاق}

بناتِ الياء والواوِ فإنَّ نظير (فُعَلاء) فيه: (أَفْعِلاء): كغني وأَغنياء وغويِّ وأغوياءً استغنوا بهذا عن (فِعالِ) وبالواوِ" (1).

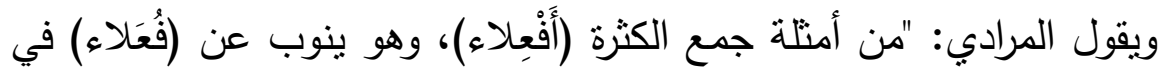

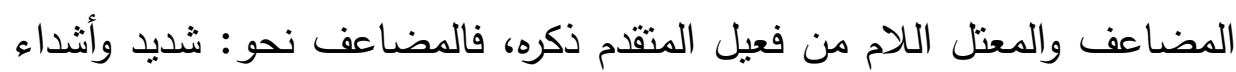
وخليل وأخلّاء، والمعتلّ نحو : غني وأغنياء وولي وأولياء، استغنوا به عن (فُعَلاء) في هذين النوعين لما فيه من الثقل"(†).

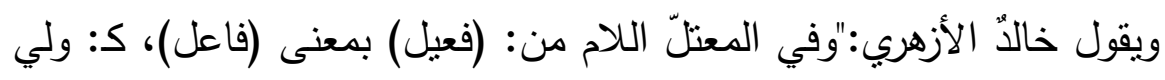

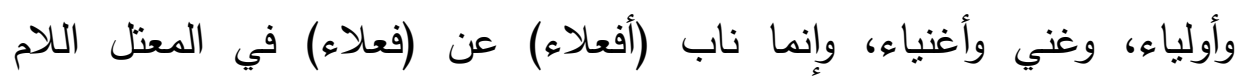

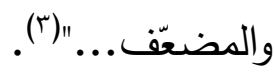

إذاً النحويون يرون أنه يجمع على (أَفْعِلاء) الصفة الرباعيّة التي على وزن

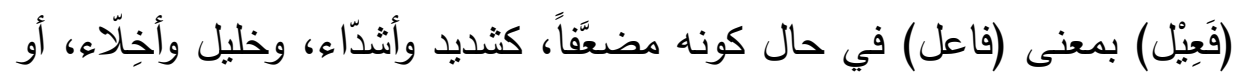

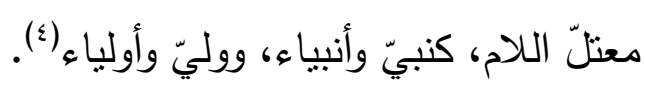
وعلّة ذلك ما يأتي:

-السّماعُ عن العرب، حيث سمع عنهم مجيء جمعهما على (أفْعِلاء)؛

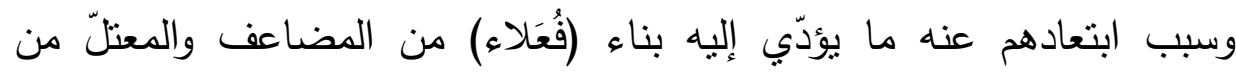

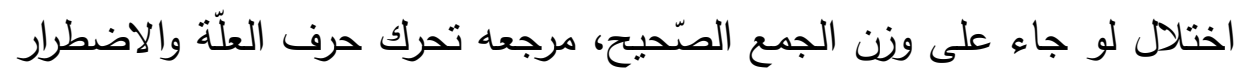

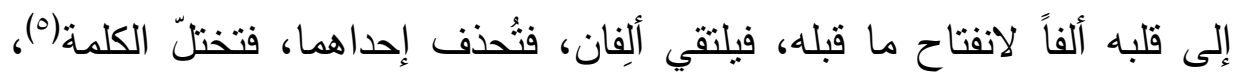

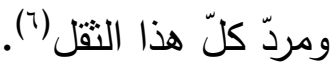

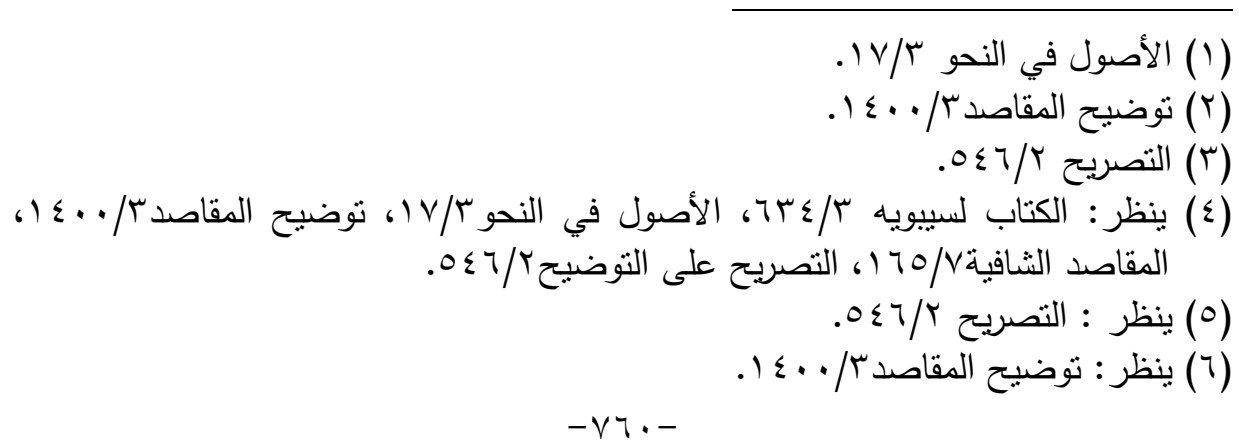




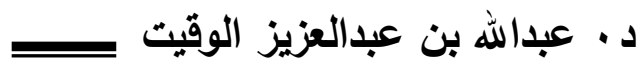

ولم يرتض بعض النّحويين هذا التعليل، وقال:"فيه نظر؛ لأنّ حرف العلة بعده ألفٌ، فلا يعلّ لأجلها، ولو قالوا: شُدَدَاء التقى حرفا التضعيف لزوال الفاصل، ولا يمكن الإدغام؛ لأن (فُعَلاء) وزن خاصٌ بالاسم، فلا يدغم"، قاله خالدٌ

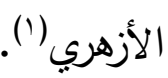

وحجة الأوّل السماع عن العرب، وحجّة الثاني القياس، والسّماع أقوى منه ما

$$
\begin{aligned}
& \text { لم يعارَضْ بسماعٍ منله، أو أقوى منه. }
\end{aligned}
$$

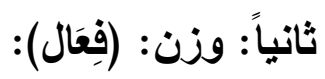

من أوزان جموع الكثرة(فِعال)، ويجمع عليه ثلاثة عشر وزناً من أوزان

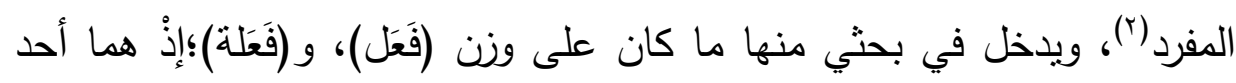

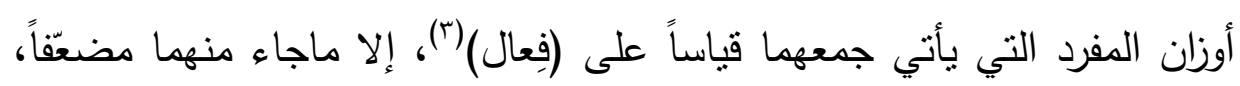

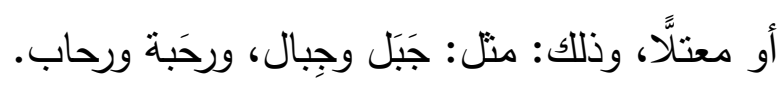

وأما المضعَّف، والمعتلّ فقد اسْنُتْنِا من هذا الوزن؛ فإنهما لا يجمعان على

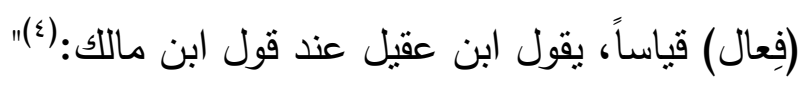

وفَعَلُ أيضًا لله فِعَال ... مالم يكن في لامِهِ اعتلال

أو يكُ مضعَّفا ومنّل فعل ... ذو التا وفعل مع فعل فاقبل

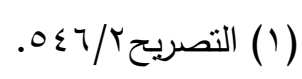

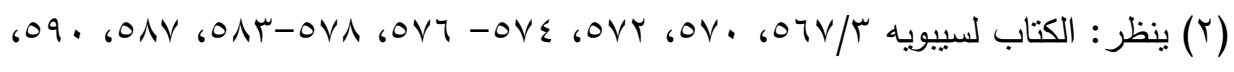

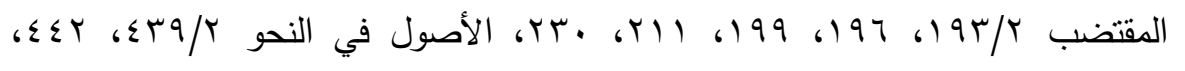

r

$$
\text { الفوائد }
$$

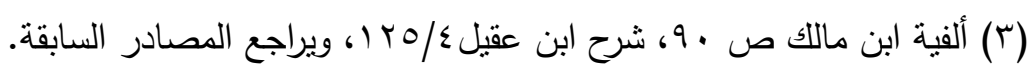

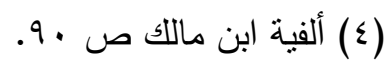




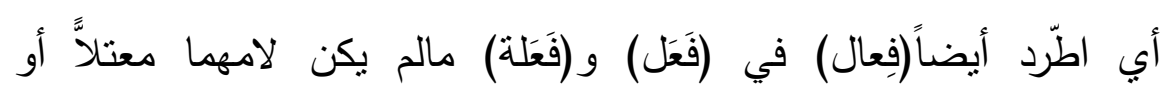

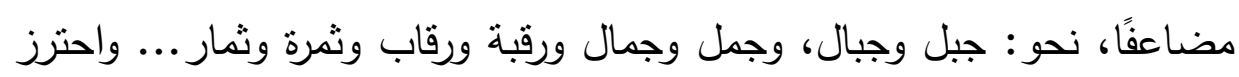
من المعتل اللام كفتى، ومن المضعّف كطلل" (1). فابن مالك انشترط لقياسية هذا الجمع شرطين، يقول الثشاطبي:"شرط فيه شرطين: أحدهما: ألا يكون معتلّ اللام... والثاني: ألا يكون مضعفاً..."(؟).

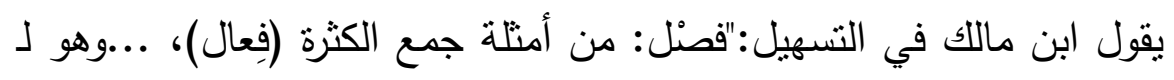

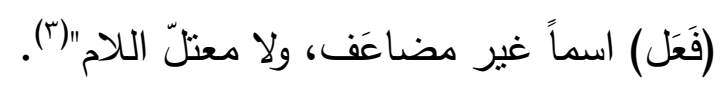

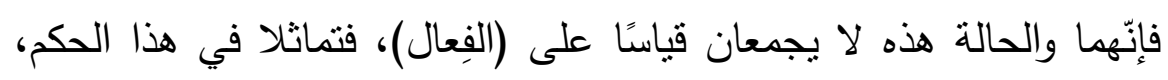

$$
\text { وخرجا بهذا الشرط(أ). }
$$

هذا قول ابن ماللك، وعليه النّحويّون فيما كان اسماً من هذا الوزن (0)، وإنما

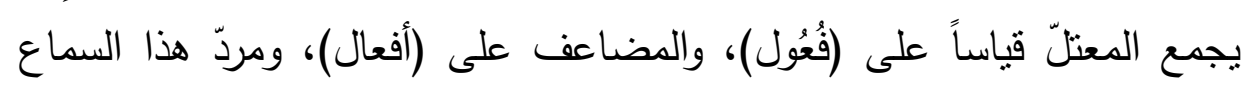

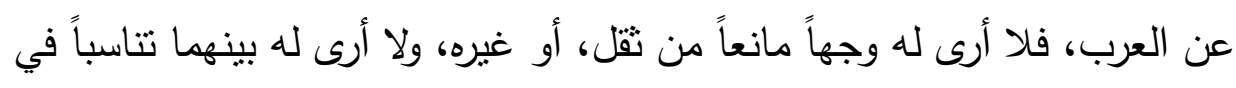

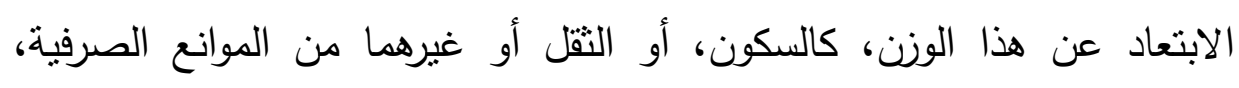
والصوتيّة. يقول سيبويه مسنداً ذلك إلى السّماع عن العرب:" وقالوا: رحى وأرحاءّ، فلم

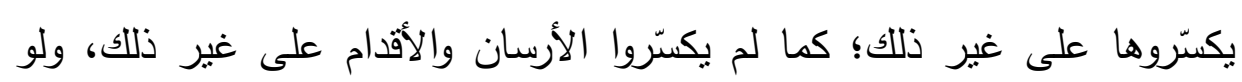
فعلوا كان قياساً، ولكني لم أسمعه" (?).

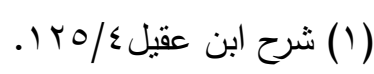

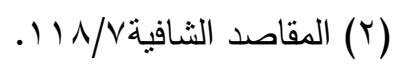

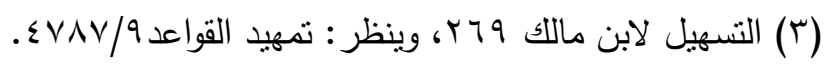

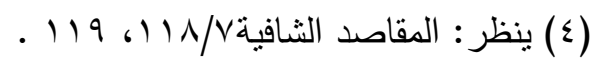

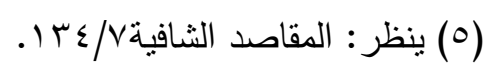

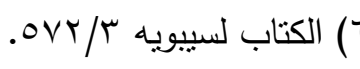


وقد خالف النحويين في هذا أبو طالب العبدي، فذهب إلى أنّ (فِعالاً)

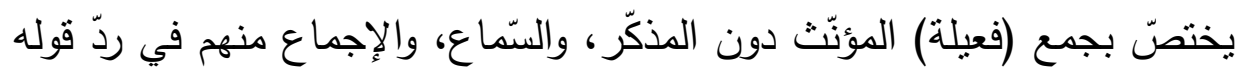
برهانُ وهن ما ذكره، أو وهم قائلها (').

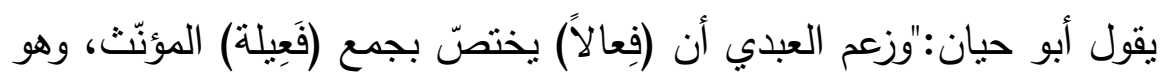

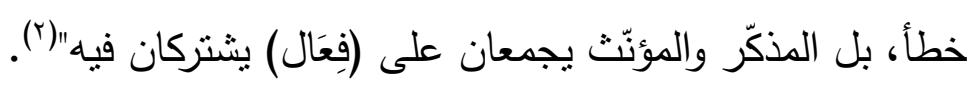
ثالثاً: وزن (أفْعال):

يطرّد وزن (أفعال) عند جمهور النحويين جمعًا للقلّة في شيئين: أحدهما: ما

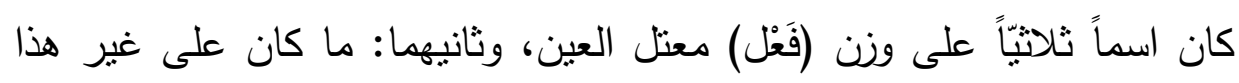

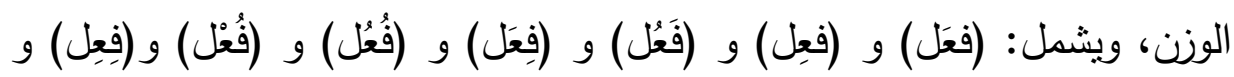
(ن)

ويدخل في مسألتي ما كان على وزن (فَعْل) منها، إذ يتّق المعتلّ

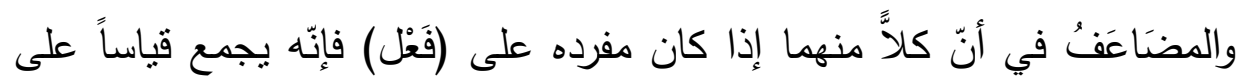

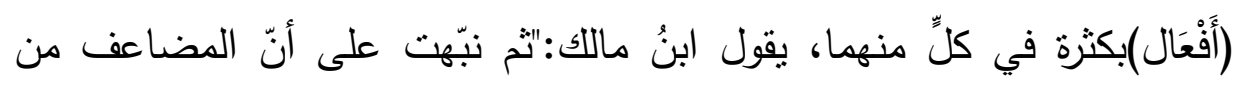

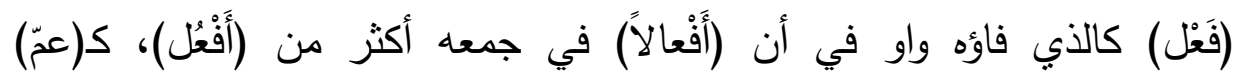

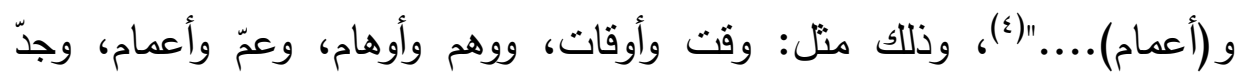

وأجاد.

فابن مالك برى-في أحد قوليه- أن جمع (فَعْل) على (أفعال) أقيس من الفي

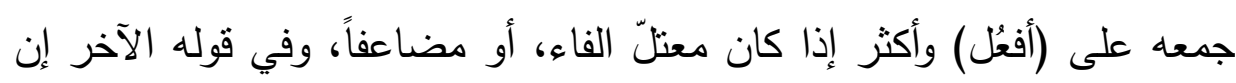

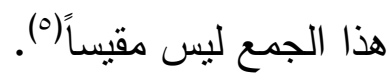

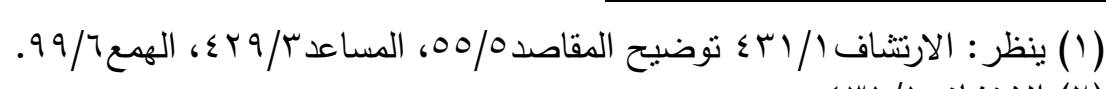

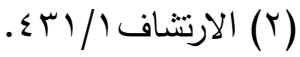

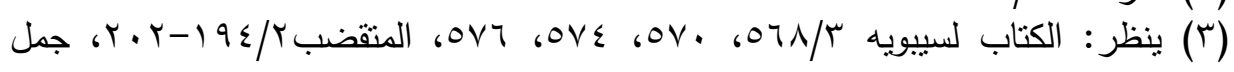

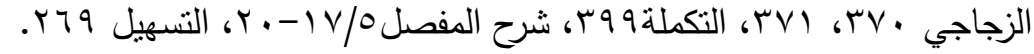




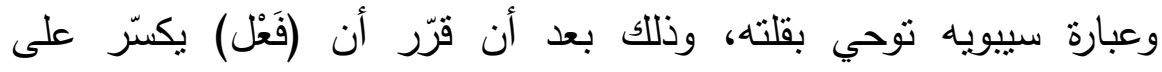

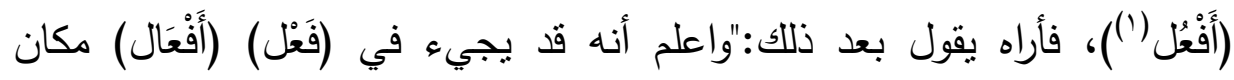

والفرق بينهما عن الصّحيح أنّ الصحيح يأني بكثرة على (أْفعل)، وبقلة على الصى

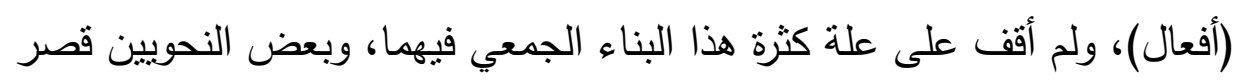

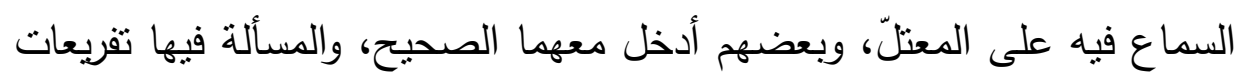
أوجزها هنا:

- أن النحويين ليسوا محلّ اتفاق في هذا الوزن، فبعضهم يذهب إلى ما

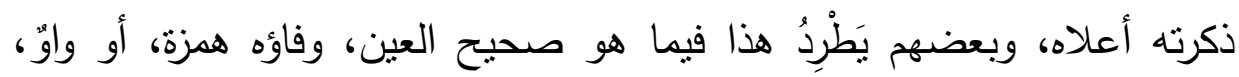
ونسب إلى الفراء) (؟).

وبعضُهم يميل إلى جعل جمع (فَعْل) على (أفعال) من الاسم الصحيح مطلقاً

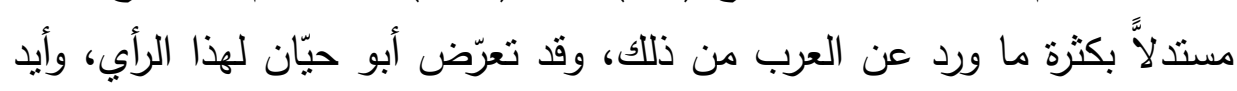

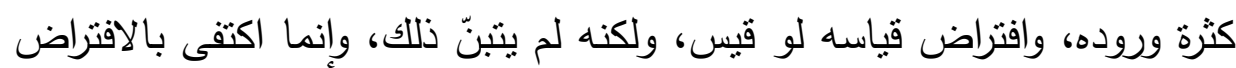

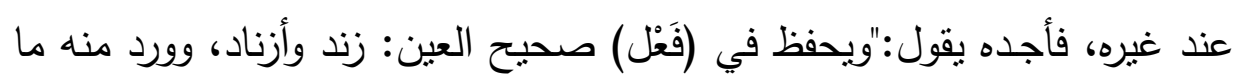

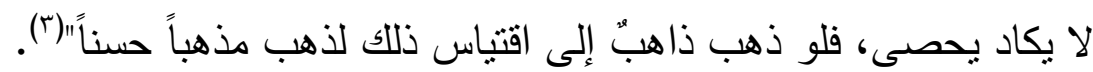

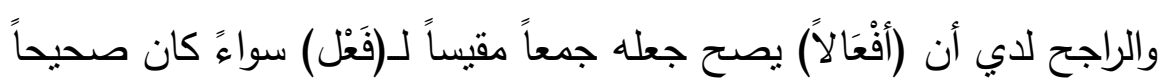

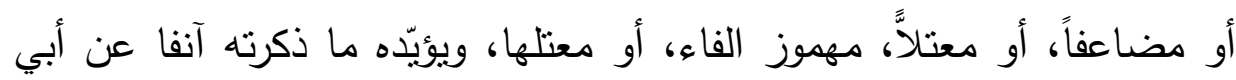

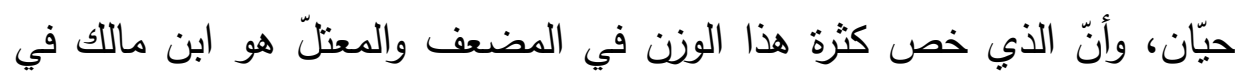

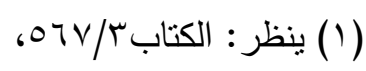

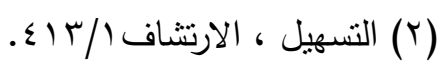

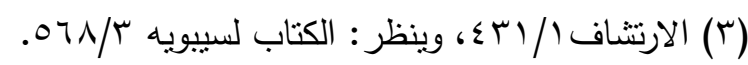

$$
\begin{aligned}
& \text {-VI }
\end{aligned}
$$


أحد قوليه، وفي قوله الآخر يذهب إلى عدم قياسيته، فيقول:"ويحفظ في (فَعْل)

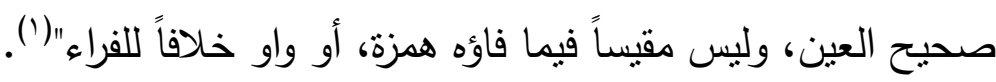
رابعاً: وزن (أَفْعَلَة):

(أفْعِلة) أحد أوزان جموع القلة، ويجمع عليه قياساً ما كان اسماً رباعيًا لمذكر

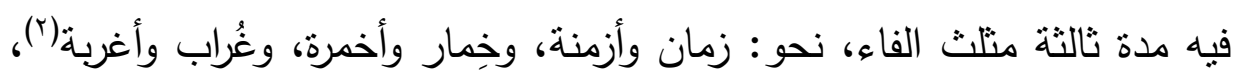

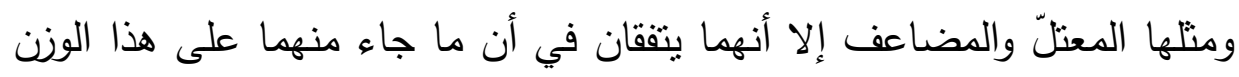

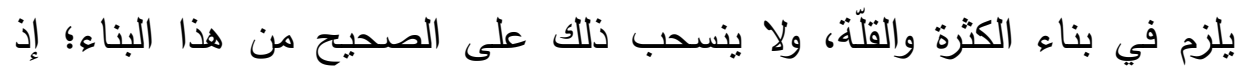

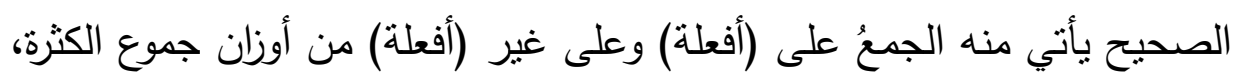

وأما هذان فيلزم لهذا البناء فيهما وزن واحد فقط، وهو (أفعلة) (r). يقول الثاطبي في معرض شرحه لنظم ابن مالك عن هذا لهاء البناء:"هذا هو

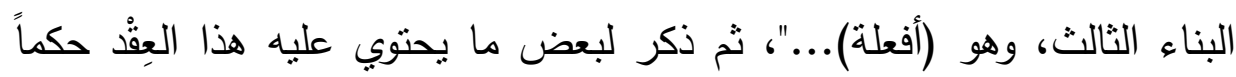

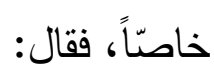

\section{والزمهه في فَعال وفِعالِ}

إلى آخره، يعني أن هذا الجمع لازم في بناعين من الأبنية التي تضمنها

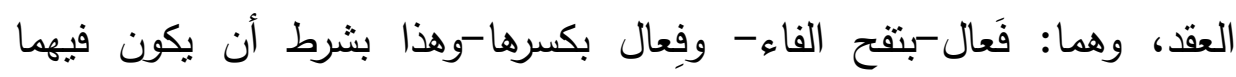

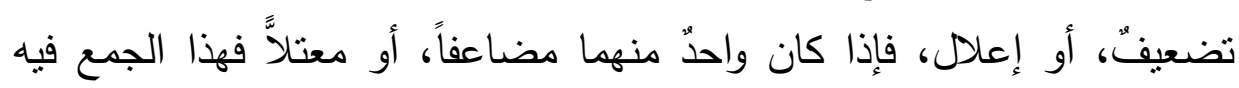
لازم، لا يعدل عنه إلى غيره بخلاف غيرهما من الأبنية المعلومة؛ فإن (أفعِلة)

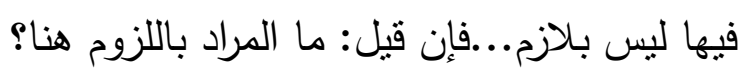
فالجواب أن مراده أن العرب ألزمت هذين البناءين هذا بلإوم الجمع في إرادة القلة

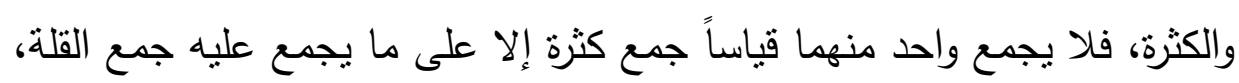


لا يجاوزون بهما بناء (أفعلة) إلى بناء كثرة، بل تقول: أسقية، وفي القليل

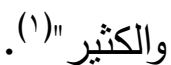

وسبب هذا السّماعُ عن العرب(r)، وأثشار إلى ذلك سييويه(r)، كما سيأتي،

ومرجعه أيضاً باب الاستغناء لايهم (๕).

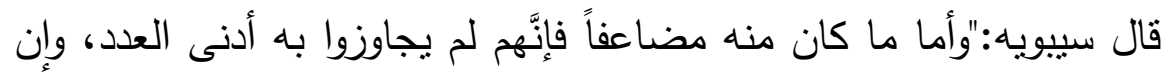

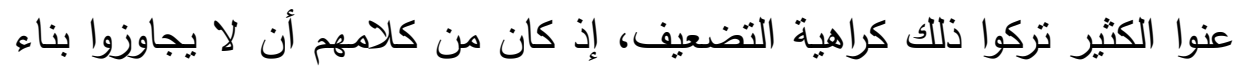

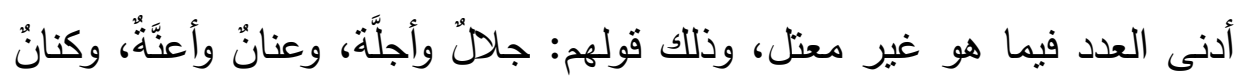

فأمّا ما كان منه من بنات الواو التي الواوات فيهن عيناتُ فإنَّك إذا أردت

بناء أدنى العدد كسّرته على أفعلةٍة..."(०). قال الثاطبي:"يعني أنهم اقتصروا على بناء القلّة"، ثم ذهب يفسر العلّة في

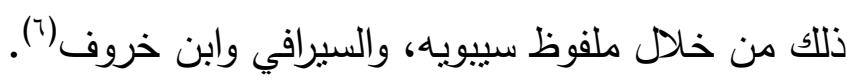
خامِساً: وزن (فُعْل):

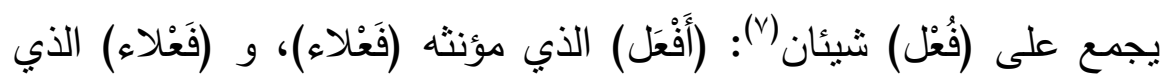

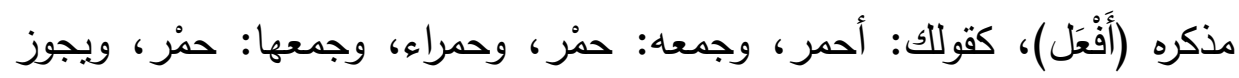

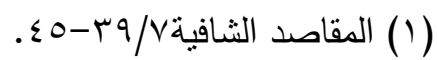

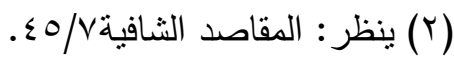

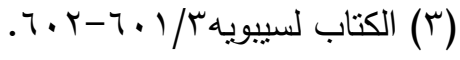

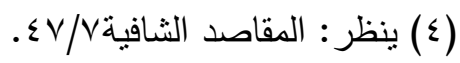

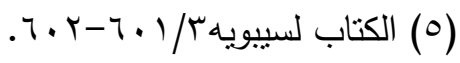

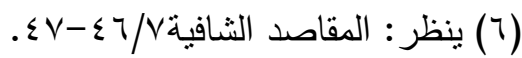

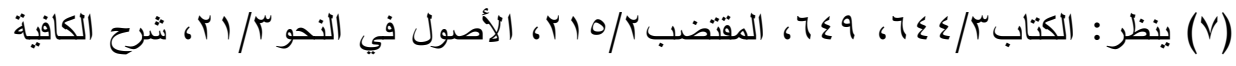

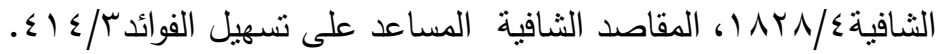




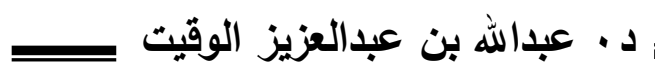

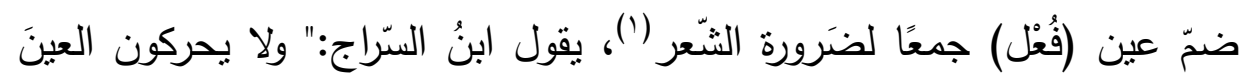

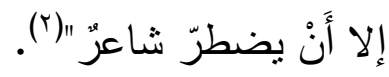

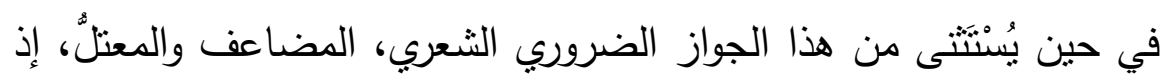

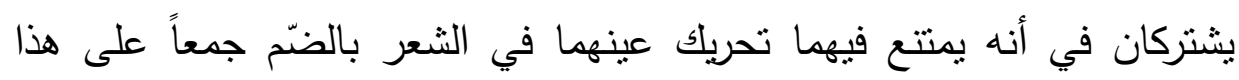
الوزن؛ إذ لا يجوز أن تحرّك العين في جمع (أغر)، ولا في جمع (أبيض) مؤنثاً،

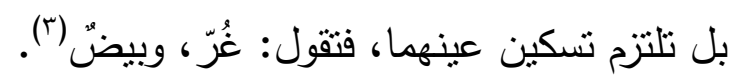
وصورة هذا ثلاثة أقسام:

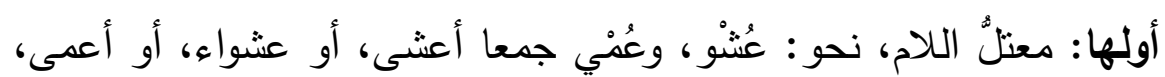

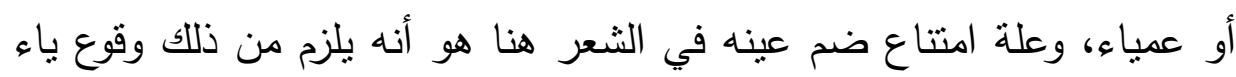

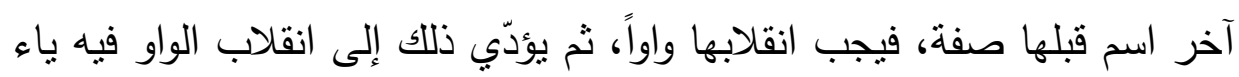

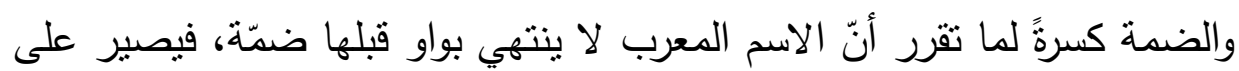

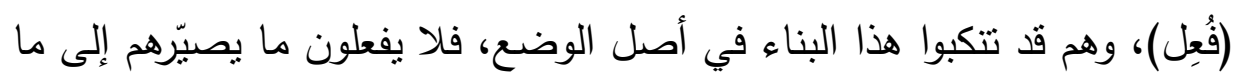
تتكبوه.

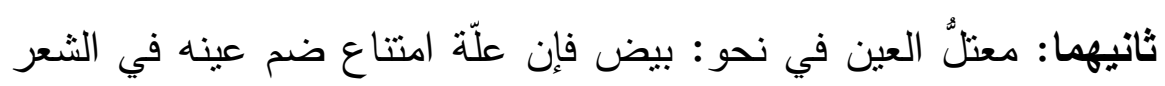

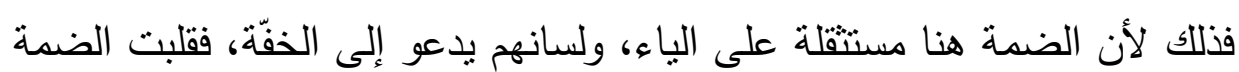
كسرة أول الأمر طلباً للخفّة. ثالثهما: المضاعف، وهو هنا مضاعف العين فإن العلة في ذلك أنه يؤدي إلى نقل الفكّّ مضموماً إلى ثقل الجمع في أصله (ء).

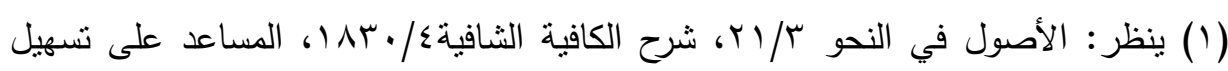

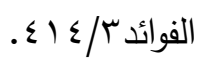

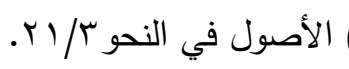

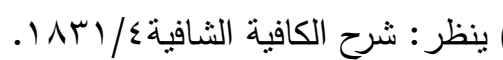

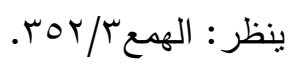




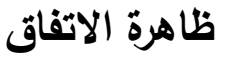

وقد عورض هذا التعليل بقول العرب: سرُر وجُد، ولم يستقلوه، مع أنه

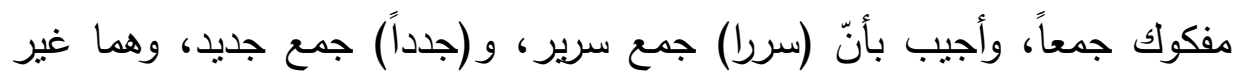

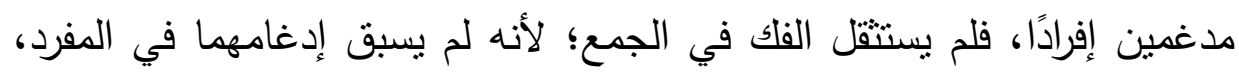

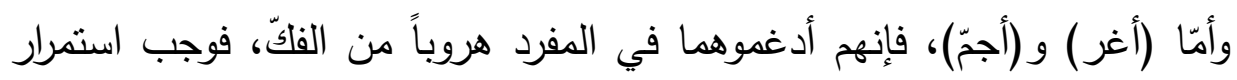

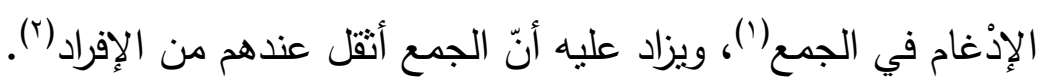

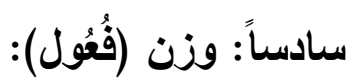

ما كانَ من المفرد على (فُعْل) اسمائيمع قياساً على (فُعُول)، وأما في

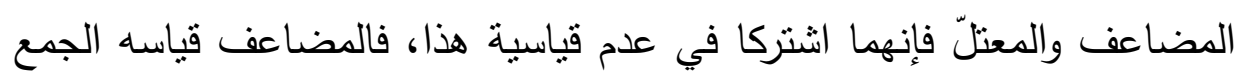

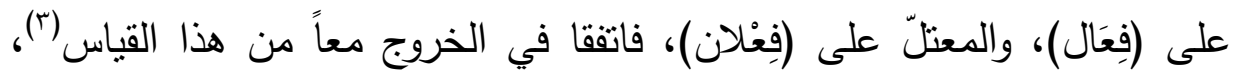

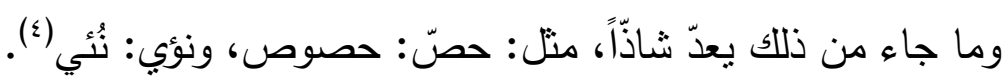
ومبنى ذلك على السّماع عن العرب، وفسر ذلك النحويون بالاستثقال.

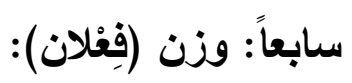

يستثنى المضتَاعف، وكذا المعتلّ العين من قياسية مجيء جمعه من (فَعَل)

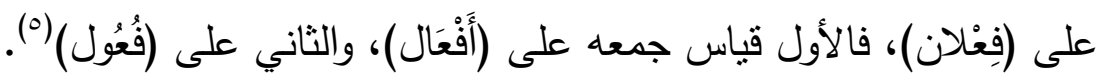

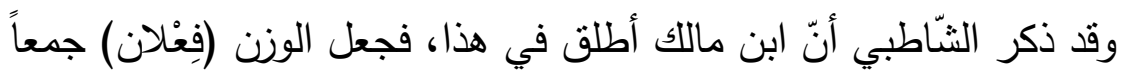

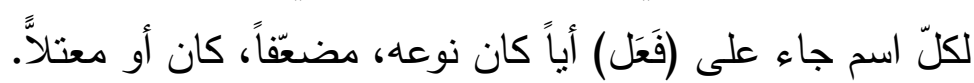

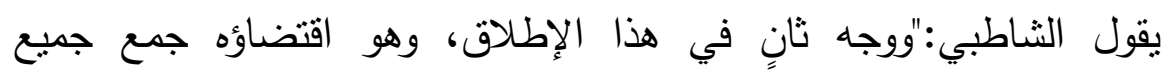

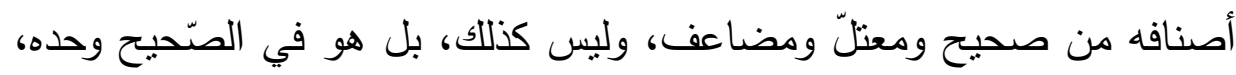

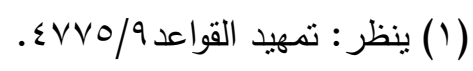

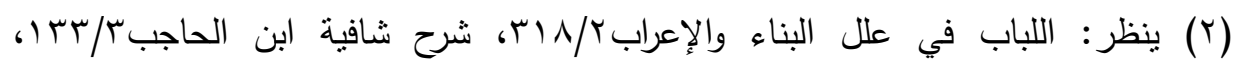

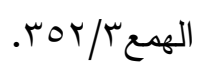

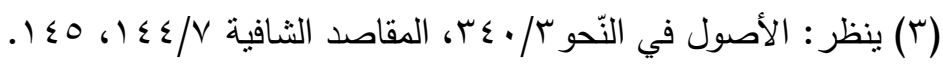

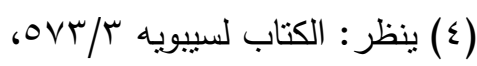

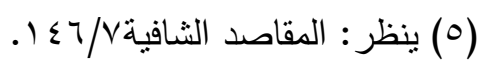




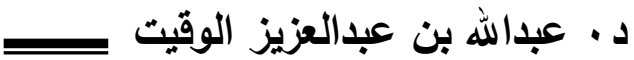

أمّا المضاعف فبابه (أَفْكال) خاصيّة، وأما المعتلّ العين فقد ذكره إثر هذا، فهو الذي نبّه على ما فيه وحده، ثم إن الناظِخَ على مقتضى هذا التفسير ينازع في كونه جعل (فِعْلان) قياسًا في (فَعَل) مع أن النحوبين سيبويه وغيره إنما ظاهر كلامهم أنه سماعُ لا قياس؛ لأنهم إنما يسوقونه مساق المنقول خاصيّة"('). ثم جعل هذا في نهاية نقاشه لإطلاق ابن مالك لهذا الحكم أنه قول له

خاصيّة، ورجّح قول الجمهور (؟).

$$
\text { ثُامناً: الجمْع على وزن (فَعَلاته): }
$$

إذا كان الاسم المفرد على وزن (فَعْلة) فإنه يجمع بفتح العين وسكونها، فيقال في تمرة: تمرات، وإذا كان معتلاً، أو مضاعفاً فإنه يلزم إسكانها، فيقال في بيضة: بيضات، وفي مرّة: مرات. جاء في اللمحة في شرح الملحة:"وإنْ كان اسمًا، ك (جَفْنَة) جُمِعَ بفتح عينه

$$
\text { وسكونها، ك (جَفَنَاتٍ) و (جَفْنَاتٍ) و (جِفَانِ) ، وكذلك (صَحْفَة). }
$$

فإنْ كان ثناني الاسم حرف عِلَّة سكنت في جَمْعِهِ، ك (بَيْضَاتٍ) و (رَوْضَتَاتِ)

$$
\text { "r؛ وتقول في المضّعف: (مَرَّاتٍ)...."(َ). }
$$

يقول ابن ماللك:"واحثُرِز بصحيح العين عن معتله، نحو: جوزة وجوزات، وديمة وديمات، وبساكن العين من متحركه، كثجرة، وسمُرة، وبنفي التضعيف من

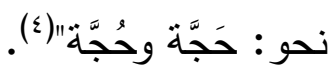

ولم يتطرق ابن ماللك إلى بيان العلّة في ذلك، ولكنْ واضحٌ أن علة ذلك عند

العرب هو التخفيف في المضاعف، واضمحلال الوزن في المعتل؛؛ إذ لو تم تحريك المعتلّ عيناً لانقلب حرف العلّة ألفاً.

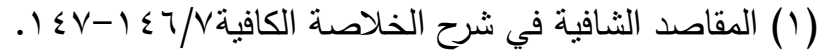

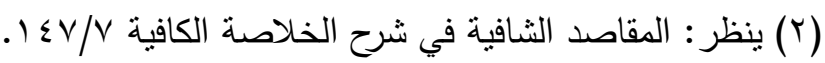

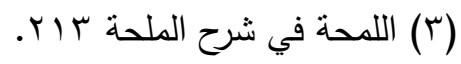

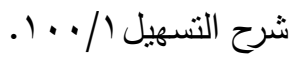


المطلبُ الثّاني: عرض أوجه الاتفاق بين المُضاعَف والمعتلّ في أوزلان غير

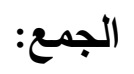

أولاً: اسمُ الفاعل واسم المفعول:

يتّقق حكم المعتلّ والمضعِق في صياغة اسم الفاعل إذا بُنبا من الفعل

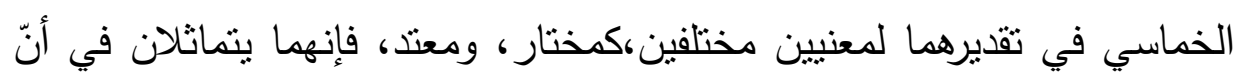

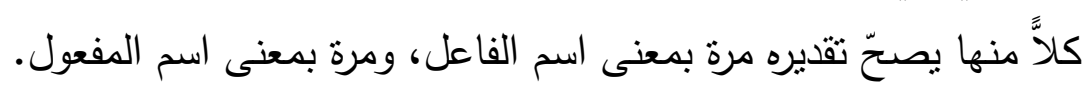

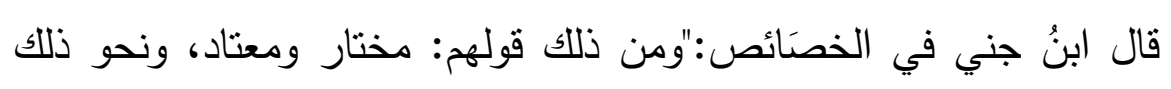

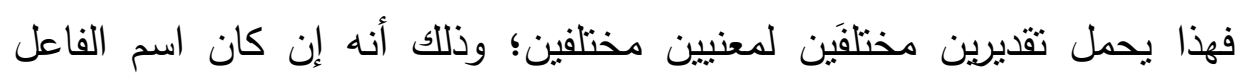

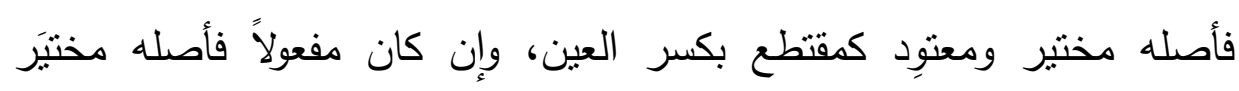
ومعتوَد كمقتطَع. فيَّ

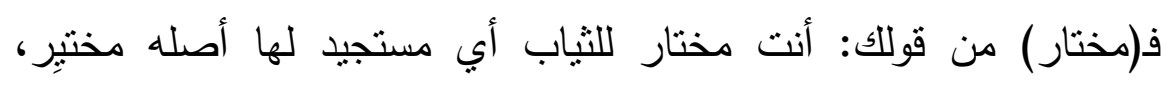

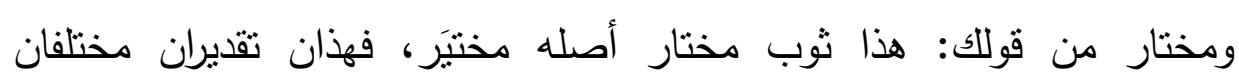

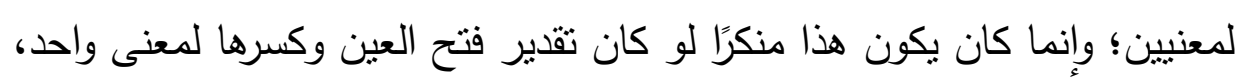

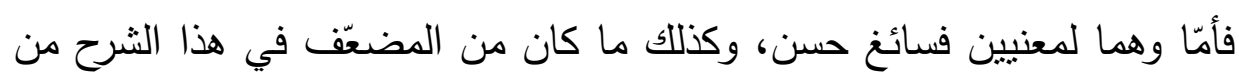

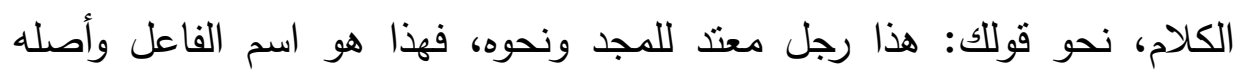

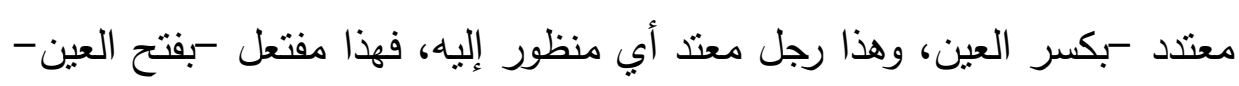

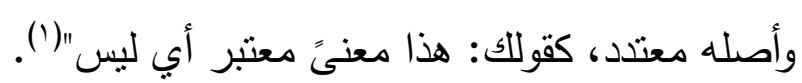

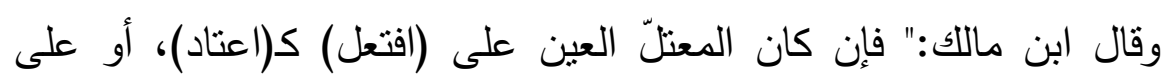

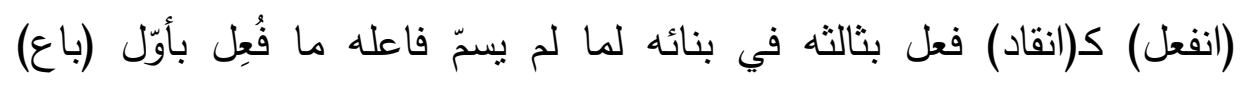

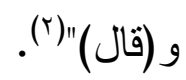

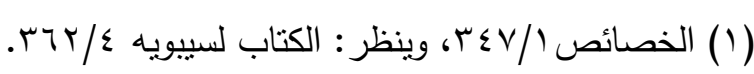

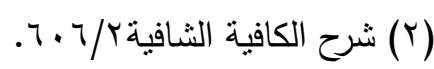

$$
\begin{aligned}
& -\gamma \vee \cdot-
\end{aligned}
$$




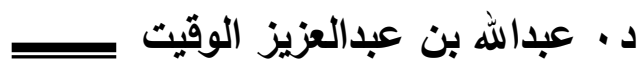

وقد عقد ابن جني لهذا باباً، وأسماه باباً في اتفاق المصاير على اختلاف

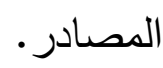

ثم قال:"من ذللك اسم الفاعل والمفعول في (افتعل) مما عينه معتلة، أو ما فيه تضعيف، فالمعتلّ نحو قولك: اختار فهو مختار، واختير فهو مختار: الفاعل والمفعول واحد لفظًا، غير أنهما مختلفان تقديرًا؛ ألا ترى أن أصل الفاعل (مختِير) بكسر العين، وأصل المفعول (مختَير) بفتحها، وكذلك هذا رجل معتاد للخير، وهذا أمر معتاد، وهذا فرس مقتاد، إذا قاده صاحبه الصاحب مقتاد له، وأما المدغم فنحو قولك: أنا معتدّ للك بكذا وكذا، وهذا أمر معتَّّ به، فأصل الفاعل (معتِدد) كمقتطع، وأصل المفعول (معتَد)، كمقتَطع، ومثله هذافرس مستن لنشاطه، وهذا

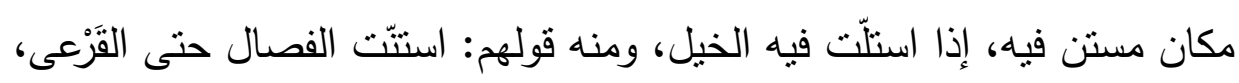
وكذلك افعَلَّ وافعالَّ من المضاعف أيضًا؛ نحو : هذا بسر محمرّ ومحمارّ ، وهذا

$$
\text { وقت محمرٌ فيه ومحمارٌ فيه" ('). }
$$

ويفرّق بين اسم المفعول واسم الفاعل فيهما بسياق الكلام.

ثُالثاً: بناء (فُقُلَ) و (فِعَلَ):

يستوي معتلّ العين والمضاعف في هذا البناء في أنهما لا بُعلّ الأوّل، ولا

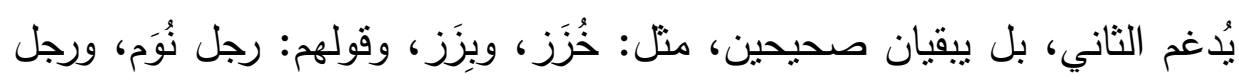
سولة، ولومة، وعيبة.

يقول المازني: "فأمّا (فُعَل)، و (فِعَل) فعلى الأصل، ولا يكون هذا البناء

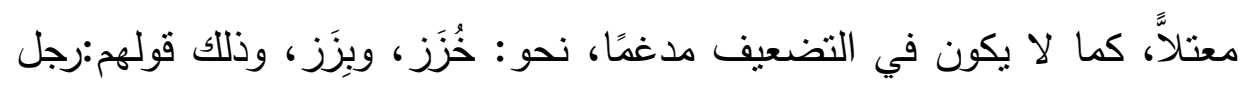

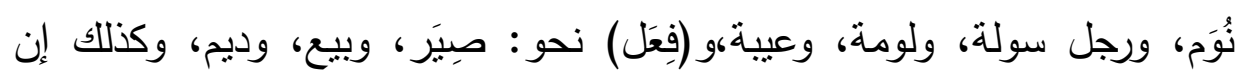
أردت منل: إبل، قلت: قِوِل، وبِيع" (r).

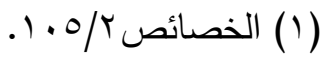

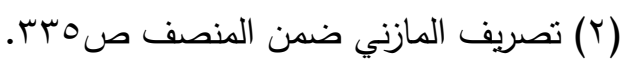




\section{ظاهرة الاتفاق}

قال ابن جني:"إنما سلمت هذه الأمتلة؛ لأنها جاءت على غير وزن الفعل،

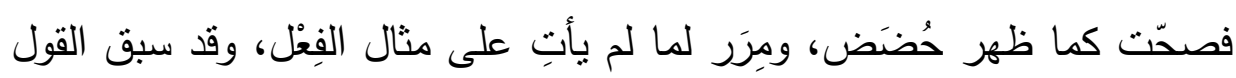
في العلّة التي من أجلها اطرّرد إعلال الفعل وتغييره" (').

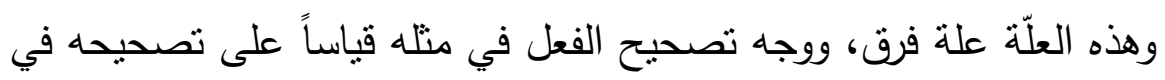

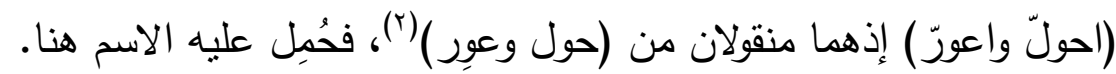

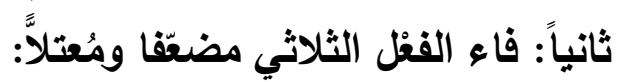

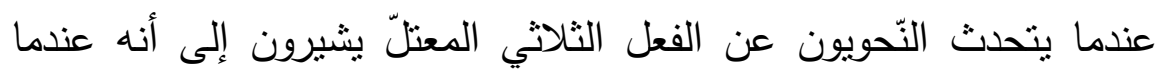

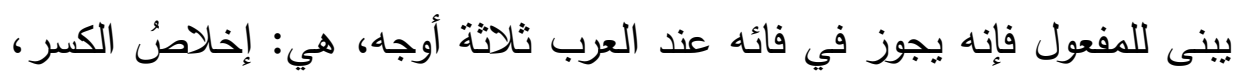

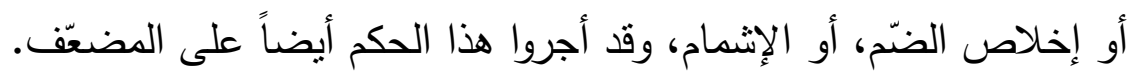

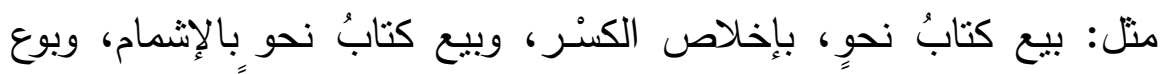

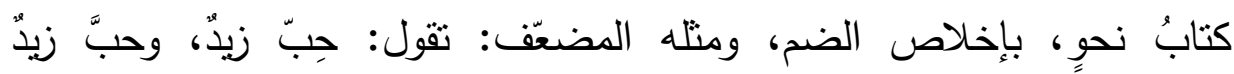

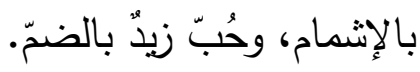

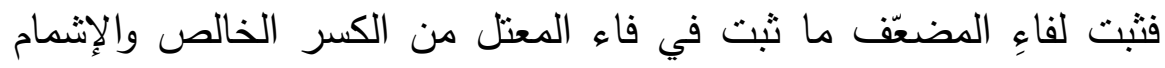
والضمّ الخالص، وقد أثنار إلى هذا ابن مالك بقوله: .

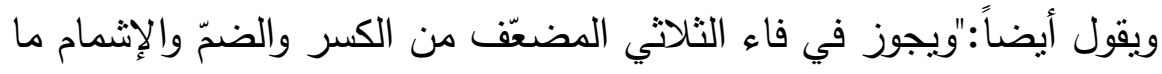

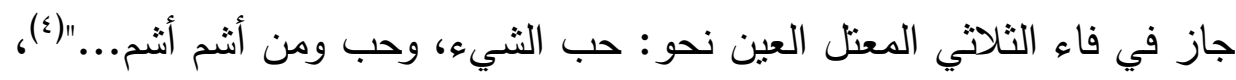

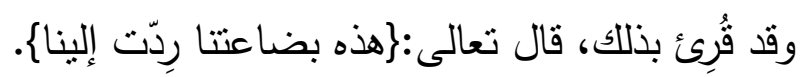

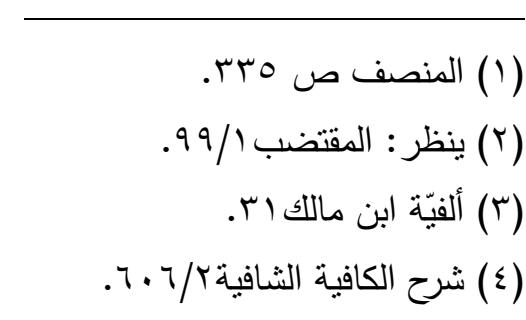




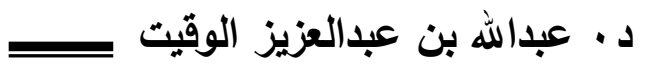

ومردّ هذا التمانل هو الستكون في ثاني كليهما، ولم تكن هذه المسألة محلَّ

$$
\text { اتفاق بين النحوبين؛ فلهم فيها قولان: }
$$

القول الأوّل: قولُ الجمهور، وهو إيجاب ضمّ فاء الثنالثي المضعَّ نحو:

$$
\text { شُد ومُد. }
$$

القول الثاني: قول الكوفيين، وهو إجازة الكسر ، وهي لغة بني ضبة، وبعض

$$
\text { تميم، وقراً علقمة : }\}
$$

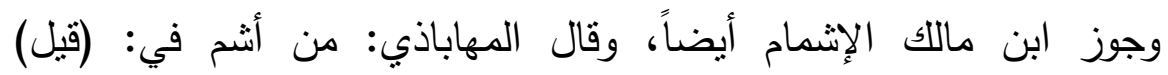

$$
\text { و: (بيع) أشم هنا" (1). }
$$

ثَالثاً:عينُ الفعل الثُلاثي مضعَّا ومُعتلاً:

إذا كان الفعل الماضي المضعَّ مكسور العين، وأسند إلى ضمير رفع إنى

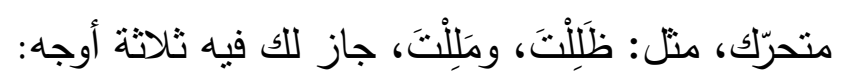

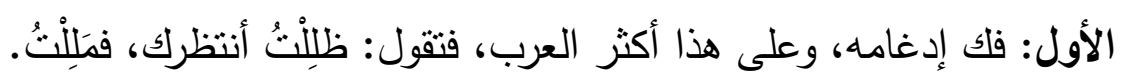

الثاني: حذف عينه مع بقاء حركة الفاء على حالها - وهي الفتحة -

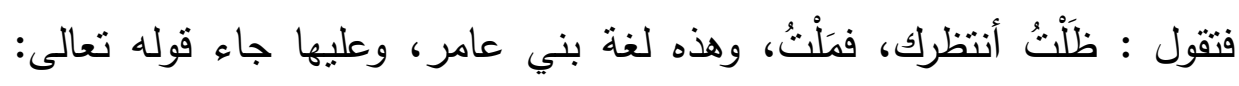
\}فظلتم تفكهون\{، وقوله تعالى:\{الذي ظلت عليه عاكفاً\{.

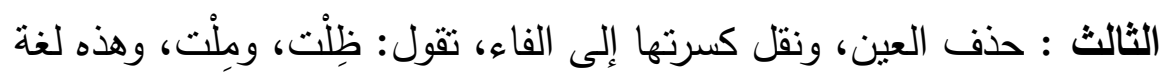

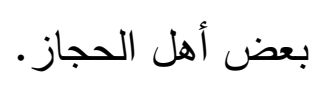

يقول سيبويه:"ومتل ذلك قولهم: ظلت ومست، حذفوا وألقوا الحركة على الفاء، الكاء

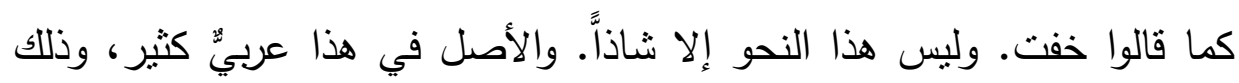

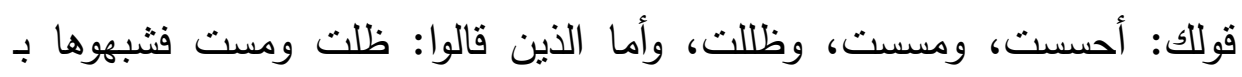

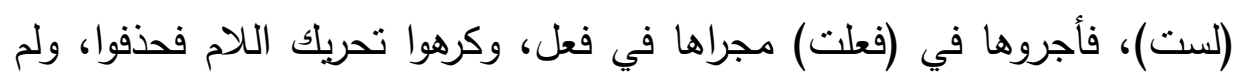




\section{ظاهرة الاتفاق}

يقولوا في (فعلت) لست البتة، لأنه لم يتمكّن تمكنَ الفعل، فكما خالف الأفعال

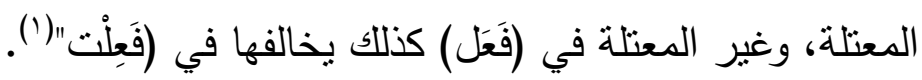

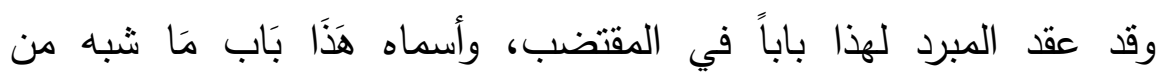

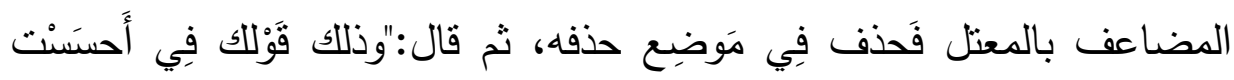

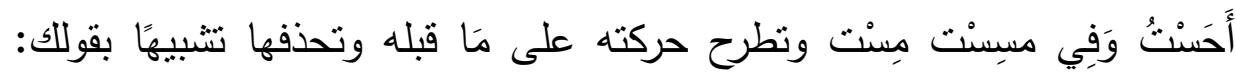

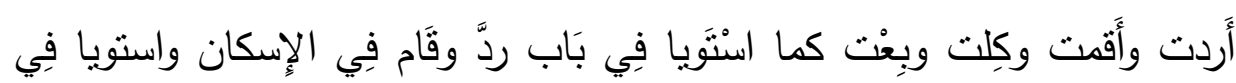

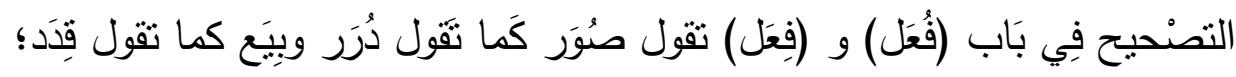

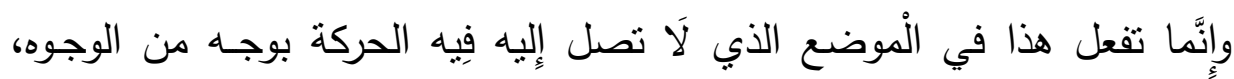
وذللك فِي (فعلت) و (فعلْنَ)" (r). رابعاً: وزن (أْفَلَ) فعلاً واسماً:

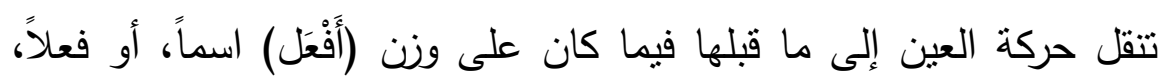

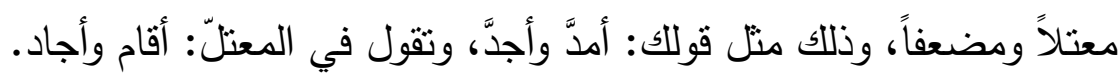

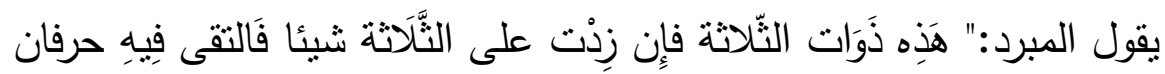

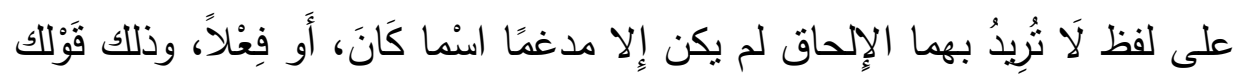

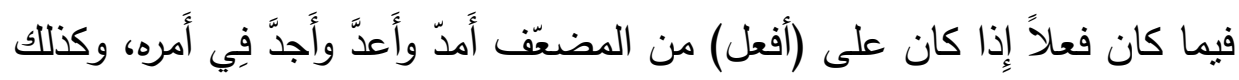

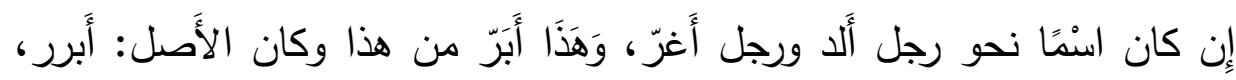

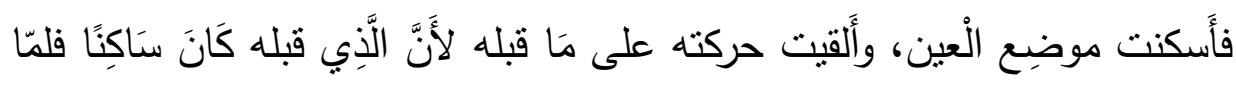

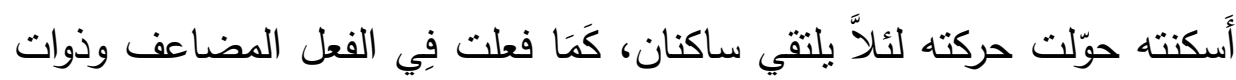

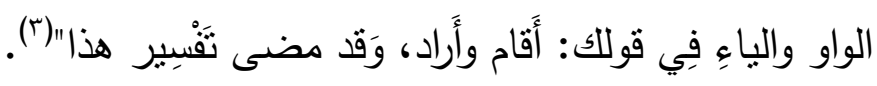

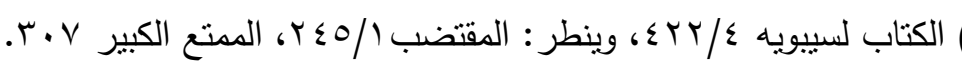

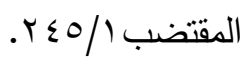

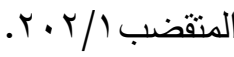


د. د عبدالله بن عبدالعزيز الوقيت

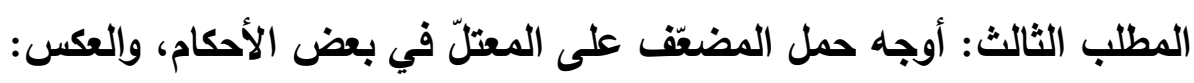

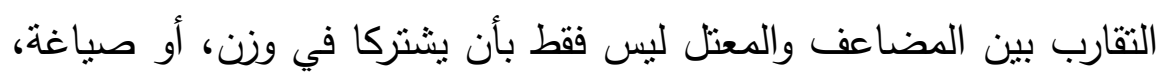

أو يستثيا من ذللك، وإنما وجدت النّحويين يحملون حكم أحدهما على الآخر ، فهما

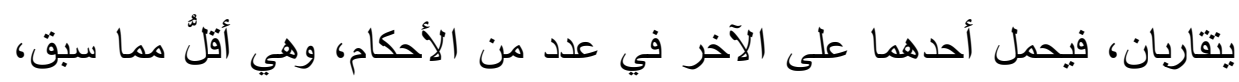

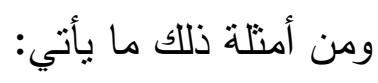

-الحكم على أصالة الواو في المعتلّ بوجودها مطرّدةً في المضعَّ:

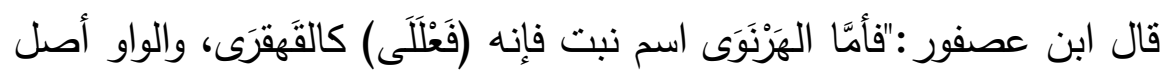

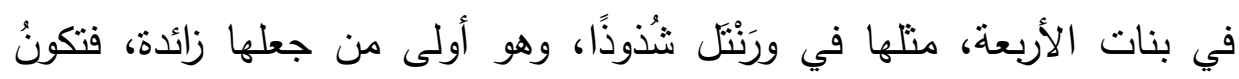

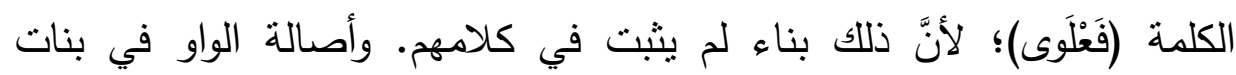

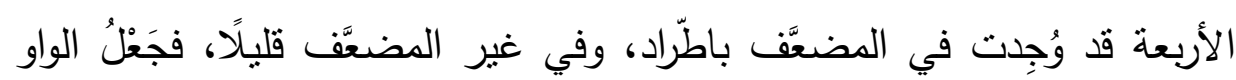

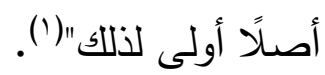

-الاستد لال على زيادة الحرف المضعَف بوقوعه موقع حرف العلة الزائد.

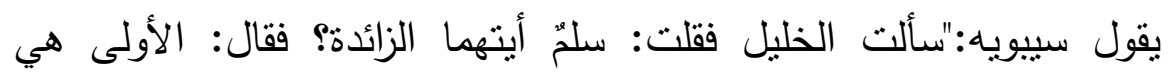

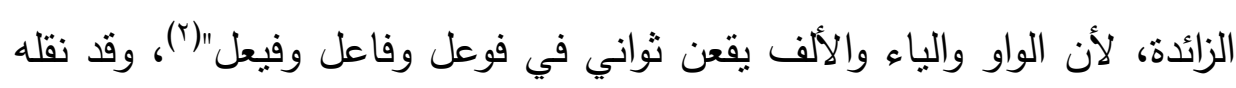
ابن عصفور والرضي عن الخليل وسييويه موافقيَن لهما(").

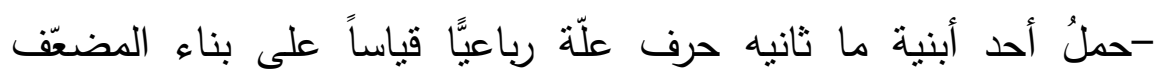
الرباعي: قال ابن عصفور أيضاً:"وأيضًا فإنَّ (فَوعالًا) كتَوراب قليلّ جدًاً، وإذا كانت

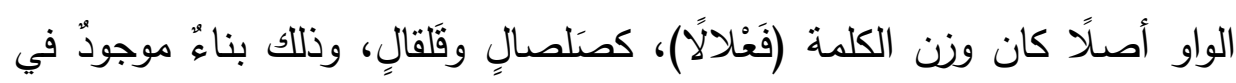
المضعَّف كثيرًا فحمله على ذلك أولى" (iٔ).

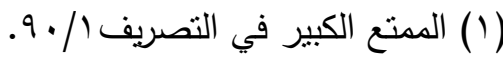

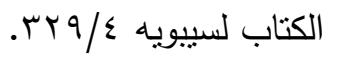

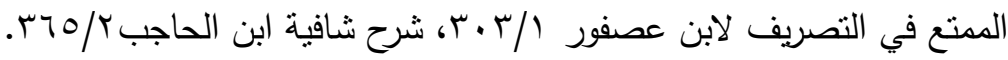

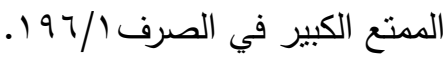


- فلكّ التضعيف بأحد حروف العلّة:

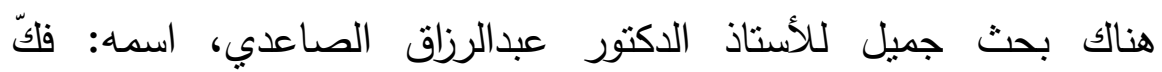

التضعيف بالإبدال، وقد عرض لكثير من هذه المسائل، ومتّل لها، وجعل الدفكوك

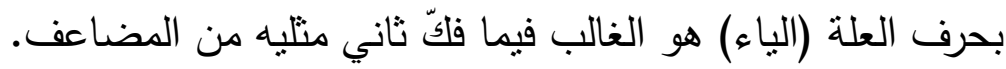

وقد منّل له في كل أنواع الأسماء والأفعال مجردًا ومزيداً (').

(1) ينظر : فلكّ التّضعيف بالإبدال صسب-. ع. 


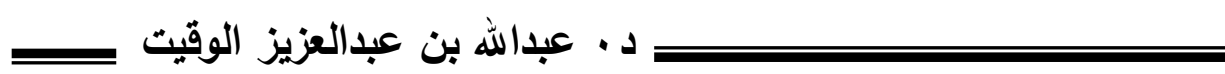

\section{الخاتِمـة}

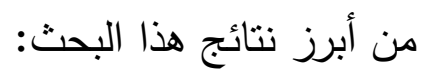

- أن ظاهرة الاتفاق في الأحكام بين المضاعف هذات والمعتلّ في التنظير الصرفي جليّة وثابتة.

- اتضح مرونة اللغة العربية في التخلّص من نقل أبنيتها، وتعدّد أمتلنها وصورها.

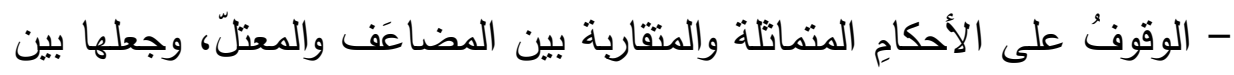
أيدي الباحثين بغية تعليلهم لهذه الظاهرة.

- تيّين استقلالية المضاعف والمعتل عن الصحيح في عدد من الأحكام ليس لئس بالقليل، وإظهار تقاربهما.

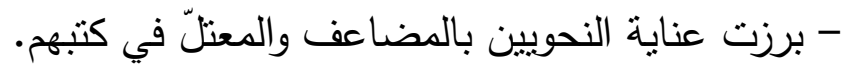

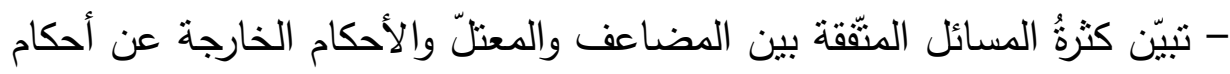
الصحيح. 


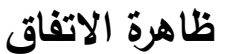

\section{ثبت المراجع والمصادر}

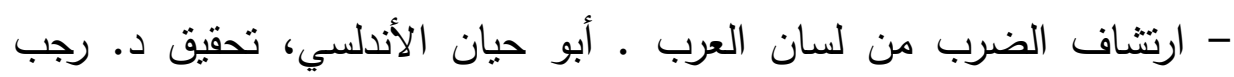

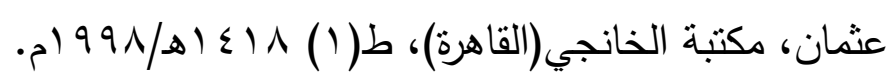

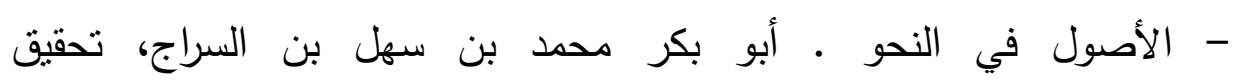

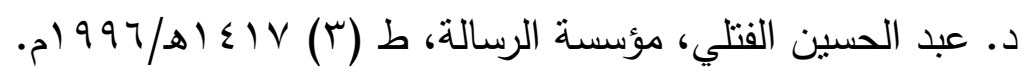

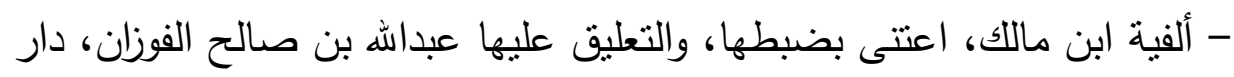

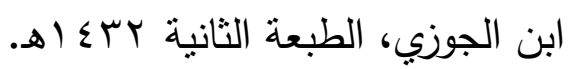

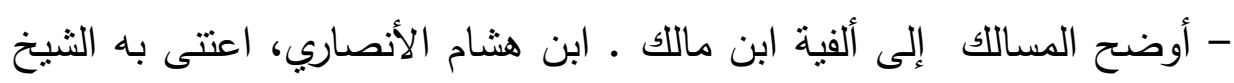
محمد محيي الدين عبد الحميد، المكتبة العصرية (لبنان). - إيجاز التعريف في علم التصريف. محمد بن عبد الله بن ماللك، تحقيق الأستاذ.

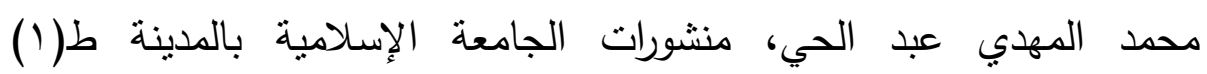

$$
\text { . }
$$

- البحر الدحيط ـ أبو حيان الأندلسي، الناشر مكتبة النصر الحديثة، الرياض.

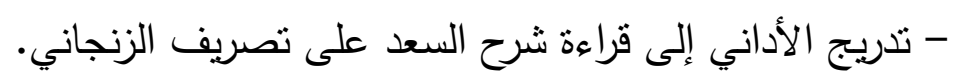

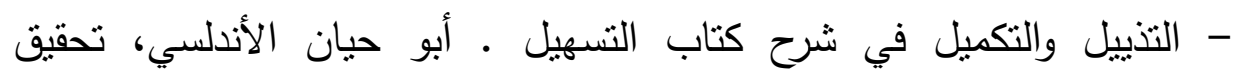

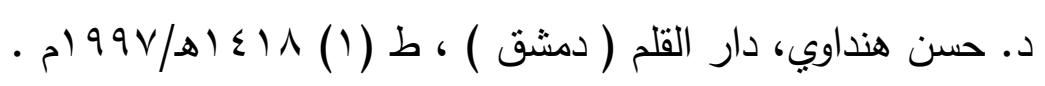

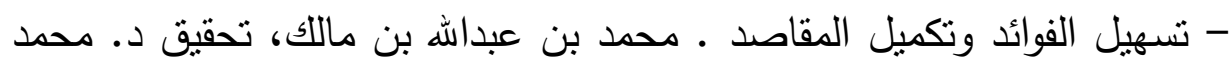

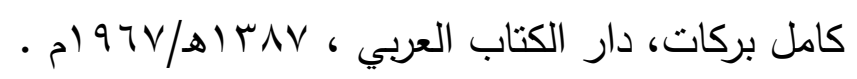

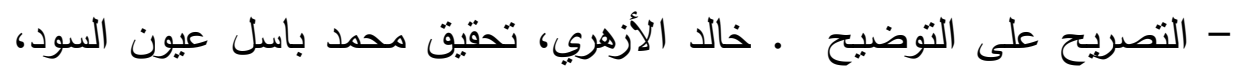

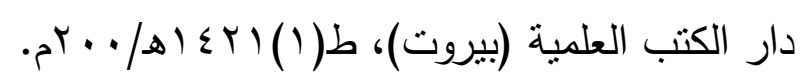

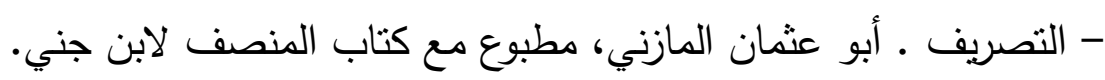

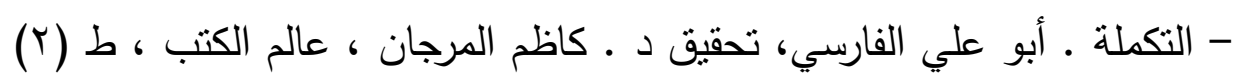

$$
\text { . م1999-ه - اله }
$$




\section{د . عبدالله بن عبدالعزيز الوقيت}

- تمهيد القواعد بشرح تسهيل الفوائد ـ ناظر الجيش، تحقيق أ ـ د. علي فاخر،

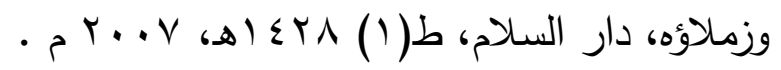

- توضيح المقاصد والمسالك بشرح ألفية ابن مالك . المرادي، تحقيق

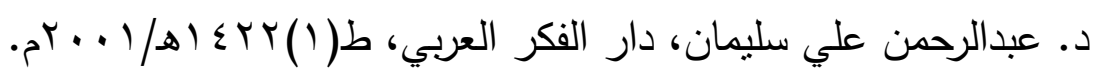

- الجمل في النحو ـ أبو القاسم عبد الرحمن بن إسحاق الزجاجي، تحقيق

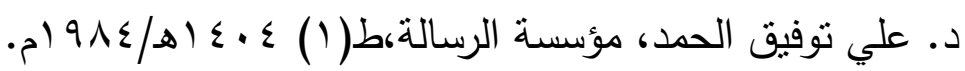

- الخصائص . أبو الفتح عثمان بن جني، تحقيق محمد علي النجار ، المكتبة العلمية.

- سر صناعة الإعراب ـ أبو الفتح ابن جني، دراسة وتحقيق د . حسن هنداوي،

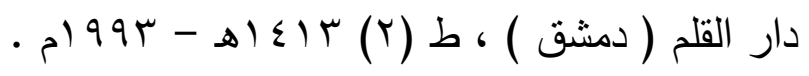

- شرح ابن عقيل على ألفية ابن مالك، تحقيق الثيخ محمد محي الدين

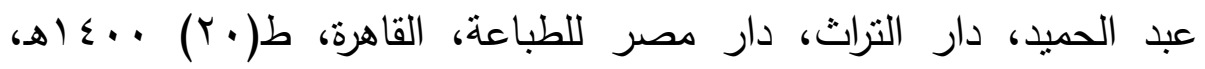

$$
\text { • م) } 9 \Lambda \text {. }
$$

- شرح التسهيل • محمد بن عبداله بن مالك، تحقيق د.عبدالرحمن السيد ود. محمد المختون، دار هجر للطباعة والنشر ، ط( () • (؟ أهـ.

- شرح التصريف • عمر بن ثابت الثمانيني، تحقيق د. إبراهيم بن سليمان

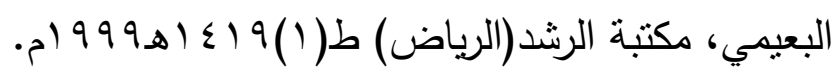

- شرح الرضي لكافية ابن الحاجب. رضي الدين محمد بن الحسن الاستراباذي: أ-القسم الأول: درسه وحققه د.حسن بن محمد الحفظي. ب-القسم الثاني: حققه د. يحيى بثير المصري، منشورات جامعة الإمام، (1) b

- شرح شافية ابن الحاجب ـ رضي الدين محمد بن الحسن الاستراباذي، تحقيق

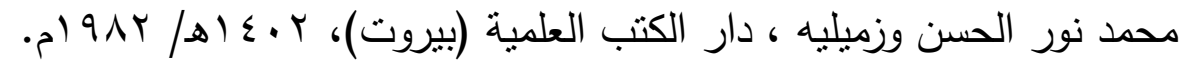
- شرح الكافية الثافية ـ محمد بن عبداله بن مالك، تحقيق د. عبد المنعم أحمد

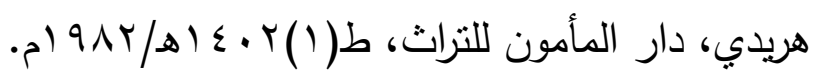




\section{ظاهرة الاتفاق}

- شرح المفصل. يعيش بن علي بن يعيش. عالم الكتب.

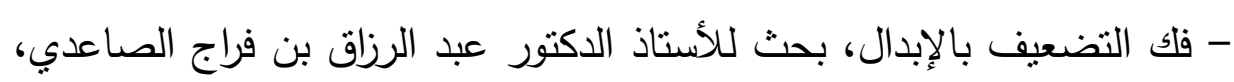

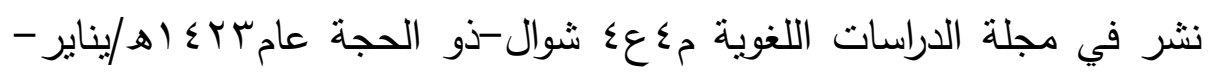

$$
\text { مارس بـ +. rم. }
$$

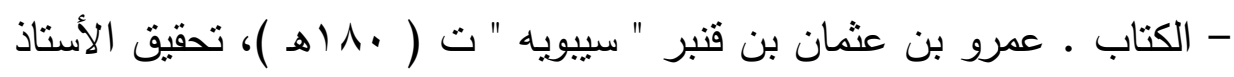

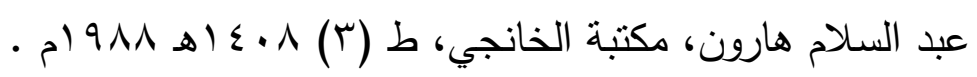

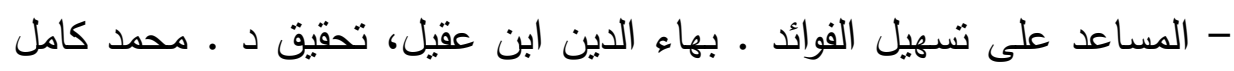

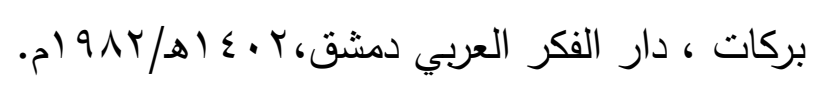

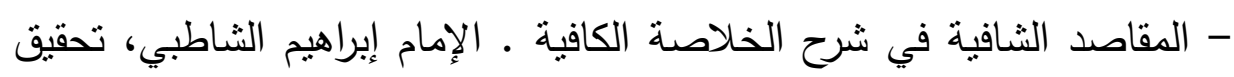

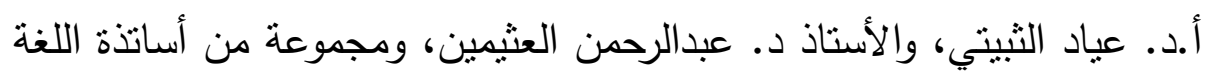

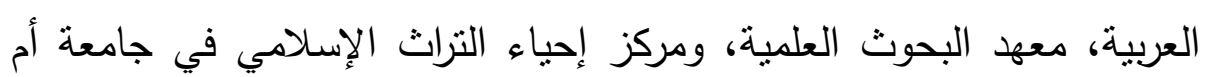

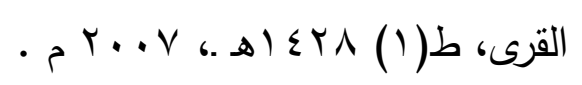

- المقتضب ـ أبو العباس المبرد، تحقيق د د ـ ـ محمد عبد الخالق عضيمة، عالم الكتب.

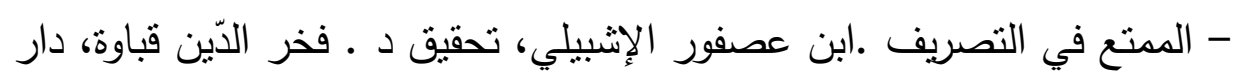

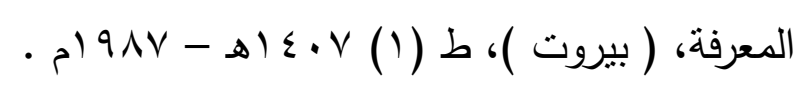

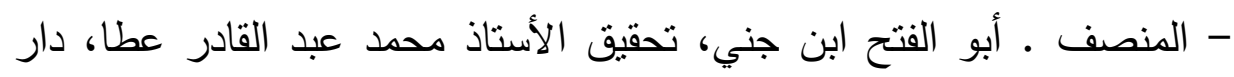

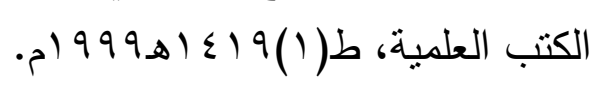

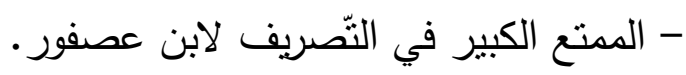

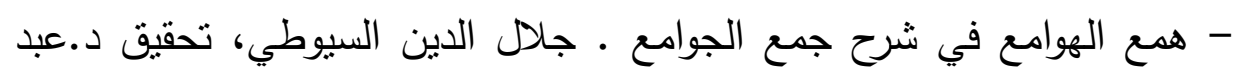

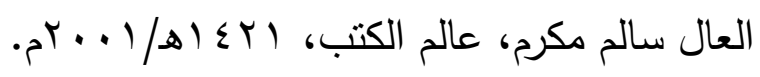

